\title{
TOMASZ WIELEBSKI \\ Horyzontalny wymiar świętowania niedzieli w Polsce. Od nauczania Magisterium do działań duszpasterskich
}

Jan Paweł II, pisząc w liście apostolskim Dies Domini w 1998 r. o kryzysie świętowania niedzieli, zaznaczył, że w niektórych regionach $z$ powodu braku silnej motywacji religijnej bardzo niewielki procent wiernych uczestniczy $w$ niedzielnej liturgii (DD 5). Papież podkreślił też, że wielu z nich zatraciło pierwotny sens niedzieli, traktując ten dzień jedynie jako zakończenie tygodnia (weekend) i będąc odświętnie ubranym, nie potrafi już świętować (DD 4). Jeżeli chodzi o pierwszą przywołaną myśl, to wydaje się że wyniki badań dominicantes i communicantes w Polsce, szczególnie w zestawieniu z sytuacją Kościoła w krajach Europy Zachodniej, są w miarę zadawalające ${ }^{1}$. Nie można oczywiście spocząć na przysłowiowych laurach, ale szukać sposobów zmiany istniejącego

Tomasz W I E L E B S K I, ks. dr hab. teologii pastoralnej, adiunkt w Instytucie Teologii Praktycznej Wydziału Teologicznego UKSW Katedra Prakseologii Pastoralnej i Organizacji Duszpasterstwa, wykładowca Wyższego Seminarium Duchownego Diecezji Warszawsko-Praskiej, e-mail: tomwielebski@gmail.com

${ }^{1}$ Od początku lat $90 . \mathrm{XX}$ w. obserwuje się z roku na rok niewielki, ale systematyczny, spadek wskaźnika dominicantes. Oznacza to, że coraz mniej Polaków uczęszcza regularnie na niedzielną mszę św. W roku 2013 wskaźnik dominicantes wyniósł 39,1\%. Zatem po raz pierwszy od 1980 roku (wynosił wtedy 51,0\%) spadł poniżej 40\%. Spadek wskaźnika dominicantes dotyczy niemal równomiernie wszystkich diecezji w Polsce. Z kolei wskaźnik wskaźnik communicantes w 2013 roku wyniósł $16,3 \%$. W stosunku do 2012 r. zaobserwowano wzrost liczby osób przystępujących do Komunii św. Z prowadzonych od $1980 \mathrm{r}$. badań wynika, że spadkowi wskaźnika dominicantes towarzyszy stale wzrost wskaźnika communicantes. Przykładowo, w Niemczech regularnie na niedzielne msze św. uczęszczało w 2012 r. 10,8\% katolików, natomiast w Hiszpanii w 2011 roku 13,0\%. Zob. P. B i e li ńs k i: Religijność w Europie; http://www. niedziela.pl/ artykul/ 10660/ Religijnosc-w-Europie (Odczyt: 19.08.2014); Dominicantes 2013; http://www. iskk.pl/kosciolna swiecie/193-dominicantes-2013.html (Odczyt: 19.08.2014). 
stanu rzeczy w kierunku liczniejszego i bardziej świadomego uczestnictwa wiernych w Polsce we mszy św. niedzielnej.

Do polskiej rzeczywistości bardziej można odnieść drugą myśl papieską dotyczącą przeżywania niedzieli w wymiarze horyzontalnym. Homo faber nie potrafi, a w niektórych sytuacjach nie chce, stawać się homo festivus. Ma to wielorakie przyczyny, a zarazem rodzi różne skutki. Mówiąc o przyczynach, należy wymienić kontekst gospodarczy i społeczno-polityczny sprzyjający zatraceniu wrażliwości współczesnego człowieka na nadprzyrodzony wymiar życia. Dobremu świętowaniu niedzieli zagraża między innymi brak świadomości religijnej czy też właściwych wzorców przeżywania czasu wolnego, niczym nie ograniczona chęć pomnażania zysku przemysłu i handlu sztucznie rozbudzających konsumpcjonizm. Z kolei do skutków nieumiejętności świętowania zaliczamy wzrastającą liczbę chorób psychicznych, postępujący rozkład rodziny, zanikanie wielorakich więzi narodowych i lokalnych.

W artykule, odwołując się do wyników własnych badań przeprowadzonych w 2009 r., uzupełnionych wynikami innych instytutów badawczych, przedstawimy problematykę świętowania niedzieli w Polsce w wymiarze horyzontalnym. Nie chodzi tylko o ukazanie stanu faktycznego pokazującego jak jest, ale zestawiając je z nauczaniem Magisterium Kościoła, mówiącym o tym, jak powinno być, chcemy wskazać na konieczność podjęcia pewnych działań. Prowadzona refleksja ma być próbą odpowiedzi na wezwanie zawarte w adhortacji apostolskiej Ecclesia in Europa z 2003 r. do podejmowania inicjatyw duszpasterskich na płaszczyźnie wychowawczej, duchowej i społecznej, pomagających przeżywać niedzielę zgodnie z jej prawdziwym sensem (EiE 81). Taki sposób działania jest realizacją jednego ze stosowanych przez teologię pastoralną paradygmatów działań, zwany paradygmatem trzech etapów analizy pastoralnoteologicznej. Ujmuje się go w formie sylogizmu praktycznego, w którym przesłanką większą jest zasada objawiona odkryta w wyniku poszukiwań nauk teologicznych, przesłankę mniejszą stanowią dane zaczerpnięte $\mathrm{z}$ prowadzonych badań socjologicznych, a wniosek, będący zasadą urzeczywistniana się Kościoła, ma charakter teologiczny. Najpierw ukazuje się jakiś wycinek działalności pastoralnej Kościoła w ujęciu normatywnym, następnie w ujęciu realizowanym, aby dojść do wniosków pastoralnych (ujęcie postulowane) ${ }^{2}$.

\footnotetext{
${ }^{2}$ W. P r z y g o d a: Paradygmaty postępowania badawczego $w$ teologii praktycznej. W: Metodologia teologii praktycznej. Red. W. P r z y c z y n a. Kraków 2011 s. 102-104.
} 


\section{Wybrane wskazania Magisterium Kościoła dotyczące horyzontalnego wymiaru świętowania niedzieli}

Dokumenty Magisterium Kościoła podkreślają, że celebracja Eucharystii stanowi centrum świętowania niedzieli i całego życia Kościoła (KL 9-10; KKK 2177; DD 32). Jest ona sercem niedzieli (DD 52). W tym bowiem dniu wierni powinni się gromadzić, aby stuchając Bożego stowa i uczestnicząc w Eucharystii, wspominać mękę, zmartwychwstanie i uwielbienie Pana Jezusa oraz składać dziękczynienie Bogu, który »przez powstanie z martwych Jezusa Chrystusa na nowo zrodzit ich do żywej nadziei« [ 1 P 1,3] (KL 106). Kościół w swoim nauczaniu podkreśla, że świętowanie niedzieli nie może jednak ograniczać się jedynie do samego przeżywania mszy św. (wymiar wertykalny), ale udział w niej oraz praktykowanie innych form życia religijnego, ma promieniować i kształtować pewien styl przeżywania niedzieli w aspekcie horyzontalnym (DD 67-72). Wypada szczegółowiej przedstawić przywołane wymiary horyzontalnego świętowania niedzielnego, aby w ich świetle spojrzeć na uzyskane wyniki badań.

W ludzką naturę jest wpisany, zgodny z wolą Boga, cykl pracy i odpoczyn$\mathrm{ku}$, który pozwala człowiekowi wyrwać się z rytmu ziemskich zajęć i uświadomić mu, że wszystko jest dziełem Bożym (DD 65). Człowiek nie może stać się niewolnikiem pracy i traktować ją w sposób bałwochwalczy (SC 74). Nieustannie trzeba pamiętać o tym, że praca jest »dla człowieka«, a nie czlowiek dla "pracy" (LE 6). Powinien on w niedziele oraz w inne dni świąteczne powstrzymywać się od prac przeszkadzających oddawaniu czci Bogu, przeżywaniu radości (...) i koniecznemu odpoczynkowi duchowemu i fizycznemu (KKK 2185; KPK 1247) wystarczajacym do prowadzenia życia rodzinnego, kulturalnego, społecznego i religijnego (KDK 67). Problem pracy w niedzielę jest ważną, nie odnoszącą się tylko do osób wierzących, kwestią etyczną. Niedziela wolna od pracy, za wyjątkiem niezbędnych usług, jest wyrazem tego, że priorytetem stają się nie kwestie ekonomiczne, ale wartości ludzkie: bezinteresowność, rodzinne i przyjacielskie relacje. Dla osób wierzących rzeczą najważniejszą staje się relacja z Bogiem i wspólnotą ${ }^{3}$.

Ważną rolę $\mathrm{w}$ świętowaniu niedzieli mają odgrywać spotkania $\mathrm{z}$ rodziną i przyjaciółmi, które powinny pomagać wyrażać pośród zwyczajnego dnia życia pokój i radość (DD 52). Spotkanie rodziców i dzieci odbywane w tym dniu mają dawać sposobność do otwarcia się na siebie oraz wzajemnego dialogu (DD 52). Dzień Pański ma być uświęcany odpoczynkiem w atmosferze chrześcijańskiej radości i braterstwa (EiE 82). Chrześcijanie mają świętować, oddając rodzinie i bliskim czas, o który trudno w pozostałe dni tygodnia (KKK 2186). Mó-

\footnotetext{
${ }^{3} \mathrm{Fran}$ c i s z e k: Przemówienie do przedstawicieli świata pracy i przedsiębiorcami na uniwersytecie $w$ Campobasso, 5 VII 2014, http://www.naszdziennik.pl/wiara-stolica-apostolska /84151,niech-niedziela-bedzie-wolna-od-pracy.html (Odczyt: 16.08.2014).
} 
wiąc o sposobie przeżywania niedzieli $\mathrm{w}$ rodzinie, warto przypomnieć wspomnienia z czasów dzieciństwa i młodości przywołane przez Benedykta XVI podczas VII Światowego Spotkania Rodzin w Mediolanie w 2012 r. Papież mówił, że świętowanie niedzieli w jego domu rodzinnym rozpoczynało się od sobotniego wspólnego czytania Pisma Świętego, przez mszę św. niedzielną, wspólny obiad, po śpiewy i wycieczki do lasu ${ }^{4}$. Podczas mszy św. celebrowanej na zakończenie spotkania rodzin papież, ukazując wartość niedzieli, zwracał uwagę $\mathrm{w}$ homilii, że jest to dzień człowieka i jego wartości: uczty, przyjaźni, solidarności, kultury, kontaktu z przyroda, zabawy, sportu. Apelował, aby rodziny wspólnie uczestniczyły w Eucharystii, spotykały się i dzieliły się sobą, broniąc wartości tego dnia, będącego jak oaza, w której można się zatrzymać, aby zasmakować radości spotkania i ugasić nasze pragnienie Boga ${ }^{5}$.

Problematykę świętowania niedzieli w gronie osób bliskich podejmuje także nauczanie Magisterium Kościoła w Polsce. II Polski Synod Plenarny poleca, aby wobec zaniku tradycji świętowania, przygotować modlitewniki i inne publikacje zawierające teksty modlitw, które rodziny mogą wykorzystać w różnych momentach życia, a także opis zwyczajów wprowadzających rodziców i dzieci w nurt chrześcijańskiej tradycji. Zachęca się rodziny do wspólnego uprawiania turystyki i zajęć sportowych, uczestnictwa w życiu kulturalnym lokalnej społeczności i narodu oraz kultywowanie rodzinnego hobby, co może przyczynić się do ograniczenia destrukcyjnego wpływu nadmiernego oglądania telewizji ${ }^{6}$. II Polski Synod Plenarny apeluje, aby uczyć rodziny dobrego przeżywania niedzieli jako dnia Pańskiego, dążąc do tego, by same zrozumiały wieloraką wartość tego dnia, a następnie przyczyniały się swoją postawą do przywrócenia jej właściwego charakteru?

Dyrektorium duszpasterstwa rodzin podkreśla, że w niedziele rodzina ma się spotykać przy wspólnym stole oraz razem spędzać wolny czas (DDR 55). Dokument zwraca uwagę na konieczność zadbania o przypominanie chrześcijańskich zasad spędzania czasu wolnego (DDR 59). Z kolei biskupi polscy w dokumencie Stużyć prawdzie o matżeństwie i rodzinie podkreślają, że relacje rodzinne spełniane w atmosferze pokoju, modlitwy, radości i zawierzenia Bogu mogą być działaniem ewangelizacyjnym, szczególnie mającym wpływ na osoby

\footnotetext{
${ }^{4}$ B e nedykt XV I: Rozmowa z uczestnikami spotkania rodzin podczas Święta Świadectw. Szczęśliwe dzieciństwo każdemu z nas daje przedsmak raju (Mediolan 2 VI 2012), „L'Osservatore Romano”. Wydanie polskie. R. 2012 nr 7-8 s. 18-19.

${ }^{5}$ B e n e d y k t X V I: Homilia podczas mszy św. na zakończenie VII Światowego Spotkania Rodzin. Aby zbudować spoleczeństwo o ludzkim obliczu (Mediolan 3 VI 2012), tamże, s. 23.

${ }^{6}$ Powolanie do życia $w$ matżeństwie i rodzinie, nr 47. W: II Polski Synod Plenarny (19911999). Poznań 2001.

${ }^{7}$ Kościót wobec życia społeczno-gospodarczego, $\mathrm{nr} 50$, tamże.
} 
przeżywające trudności rodzinne ${ }^{8}$. Natomiast $\mathrm{w}$ liście Zachowujcie niedzielę, a niedziela zachowa wasza rodzinę biskupi zaznaczają, że niedziela pozwala rodzinie poznać smak zachwytu nad dzietem stworzenia i daje szansę dla zabieganej rodziny do intensywnego spotkania z Bogiem i między sobą. Posiłek świąteczny, właściwy strój i brak pośpiechu mają pomóc w doznawaniu odczucia innego świata, który jest celem życiowej pielgrzymki. Biskupi apelują, aby cała rodzina zasiadała do stołu, modląc się przed i po posiłku oraz dzieliła się wspólnymi przeżyciami, by odkrywać świat, opowiadać o swoich sukcesach i porażkach, a w ten sposób budować prawdziwa jedność $w$ rodzinie 9 . W niedzielę wszyscy mają się radować się z piękna stworzonego świata, wspólnie spędzać czas na łonie przyrody, organizować wyjazdy rodzinne i wycieczki a także spotykać się z innymi rodzinami. Biskupi przestrzegają przed robieniem $\mathrm{w}$ tym dniu zakupów, ucieczce $\mathrm{w}$ świat wirtualny, nadmiernym spędzaniem czasu przed telewizorem czy komputerem ${ }^{10}$. Zachęcają, aby $\mathrm{w}$ tym dniu podejmować rozmowy z dziećmi na tematy religijne, czytać wspólnie Pismo Święte, czasopisma i książki religijne, korzystać z katolickich mediów, odmawiać rodzinny różaniec, nawiązywać w rozmowach do czytań mszalnych i usłyszanego kazania. Wspólne przebywanie i modlitwa, podkreślają pasterze Kościoła, służą uczeniu się dialogu między rodzicami i dziećmi, budowaniu jedności i dostarczaniu wzajemnego wsparcia ${ }^{11}$.

Według nauczania Magisterium, w niedzielę wierni mają korzystać z należnego odpoczynku duchowego i fizycznego (KPK 1247). Odpoczynek niedzielny, pozwalając sprowadzić do właściwych proporcji troski i codzienne zajęcia, nie może się stać wywołującą uczucie nudy jałową bezczynnością, ale musi być źródtem duchowego wzbogacenia, zapewniając większa wolność, umożliwiać kontemplację i sprzyjać braterskiej wspólnocie (DD 67-68). Ważną rzeczą jest rodzaj aktywności podejmowanej w niedzielę przez chrześcijan. Niedziela ma być czasem refleksji, ciszy, lektury i medytacji sprzyjajacych wzrostowi życia wewnętrznego (KKK 2186). Potrzeba popierać takie przeżywanie niedzieli, które, będąc związane z udziałem $w$ różnych formach aktywności kulturalne, politycznej lub sportowej, przyczynia się do rozwoju i postępu życia człowieka (DD 4). Niedziela może też stać się czasem odkrywania i zachwycania się pięknem przyrody (DD 67).

${ }^{8}$ Rada ds. Rodziny Konferencji Episkopatu Polski: Stużyć prawdzie o malżeństwie i rodzinie (19 VI 2009). Warszawa 2009 nr 129.

${ }_{9}$ List pasterski Episkopatu Polski na Niedzielę Świętej Rodziny. Zachowujcie niedzielę, a niedziela zachowa wasza rodzine, Warszawa 2012, $\mathrm{nr}$ 2, http://www.duszpasterstworodzin.gniez no.opoka.org.pl/go.php/pl/dokumenty_kosciola_o_rodzinie/komisja_episkopatu_polski/_list_paster ski_episkopatu/zachowujcie_niedziele_a_niedziela.html (Odczyt: 2.03.2013).

${ }^{10}$ Tamże.

${ }^{11}$ Tamże, nr 3. 
Ważną rolę w świętowaniu niedzieli odgrywa parafia, stwarzając różne formy przeżywania dnia Pańskiego. II Polski Synod Plenarny zwraca uwagę na to, że wśród różnych zadań parafii powinno znaleźć się kształtowanie umiejętności społecznych i postaw obywatelskich przez naukę współpracy w grupach i wspólnotach, bibliotekach, wideotekach, kawiarenkach, klubach sportowych, centrach młodzieżowych i klubach „trzeciego wieku” ${ }^{2}$. Apeluje on do duszpasterzy, aby popierali tworzenie przy parafiach różnego rodzaju miejsc, w których rodziny moga wzajemnie poznawać się, wymieniać poglady $i$ wspólnie spędzać $c z a s^{13}$. Synod postuluje, aby powrócić do rozwijanej przed wojną idei domów katolickich, wykorzystując nieużywane pomieszczenia, w których kiedyś odbywały się zajęcia katechetyczne. Zadaniem tych domów miałoby być rozwijanie kultury duchowej i fizycznej młodzieży, ukazywanie miejscowej tradycji chrześcijańskiej, ożywianie działalności drużyn harcerskich, popieranie miejscowej działalności artystycznej przy współpracy z powiatowymi i gminnymi placówkami kulturalnymi ${ }^{14}$. Wzywa się każdą parafię do prowadzenia czytelni i bibliotek parafialnych, systematycznie uzupełnianych o nowe publikacje, przede wszystkim religijne ${ }^{15}$. W podobnym duchu wypowiada się Dyrektorium duszpasterstwa rodzin, apelując, żeby tam, gdzie jest to możliwe, organizować parafialne kluby młodzieżowe, sportowe, czytelnicze i dyskusyjne, a także kluby seniora dla starszych, samotnych i opuszczonych (DDR 59).

Jednym z wymiarów świętowania niedzieli, będącym konsekwencją udziału w Eucharystii, ma być pełnienie dzieł miłosierdzia i działalność charytatywna (KL 9; DD 69). Fala miłosierdzia, wzbudzona przez udział w niedzielnej Mszy św., ma kształtować sposób przeżywania tego dnia. Chrześcijanie muszą szukać ludzi potrzebujących jego wsparcia, poświęcając kilka godzin jakieś konkretnej formie wolontariatu i solidarności (DD 72). W pobożności chrześcijańskiej niedziela jest dniem tradycyjnie poświęconym na dobre uczynki i pokorne postugi względem ludzi chorych, kalekich i starszych, o których chrześcijanie mają zawsze pamiętać (KKK 2186). Głoszenie słowa Bożego (kerygmat - martyria), sprawowanie sakramentów (leiturgia) oraz posługa miłości (diakonia) są ze sobą bardzo ściśle związane, wyrażając naturę Kościoła (DCE 25). Z dnia Pańskiego trzeba uczynić dzień szczególnej solidarności z tymi wszystkimi, którzy właśnie w niedzielę boleśnie odczuwaja swoją samotność, ubóstwo i cierpienie (DD 72). Zwłaszcza w czasach współczesnych potrzebna jest nowa wyobraźnia miłosierdzia, której przejawem będzie nie tylko skuteczność pomocy, ale również zdolność solidaryzowania się z cierpiącym bliźnim (NMI 50). Przez posługę miłości

${ }^{12}$ Potrzeby i zadania nowej ewangelizacji na przełomie II i III Tysiąclecia Chrześcijaństwa, nr 48. W: II Polski Synod Plenarny (1991-1999), dz. cyt.

${ }^{13}$ Powotanie do życia $w$ matzeństwie i rodzinie, $\mathrm{nr} 44, \mathrm{dz}$. cyt.

${ }^{14}$ Ewangelizacja kultury i środków społecznego przekazu, nr 64 W: II Polski Synod Plenarny (1991-1999), dz. cyt.

${ }^{15}$ Tamże, nr 66. 
(diakonia) wyraża się istota Kościoła, który nigdy nie może być uwolniony od czynienia posługi caritas jako uporządkowanej działalności wierzących (DCE $25 ; 29)$.

Benedykt XVI, w przemówieniu do trzeciej grupy biskupów polskich przebywających w Watykanie z wizytą ad limina Apostolorum w 2005 r., zwracał uwagę na różne formy wolontariatu organizowane w Polsce, mające na celu pomoc osobom przebywającym w hospicjach, schroniskach dla bezdomnych, uzależnionym, samotnym matkom i ofiarom przemocy, chorym, samotnym, rodzinom wielodzietnym i ubogim, osobom upośledzonym umysłowo i fizycznie. Wymieniając różne formy pracy, apelował, aby doceniać wszystkich działających na wzór miłosiernego Samarytanina, wspierając i animując ich działania ${ }^{16}$. Z kolei papież Franciszek, przemawiając do polskich biskupów w 2014 r., zwrócił uwagę, że Kościół w Polsce ma być blisko ubogich: potrzebujących, bezrobotnych, bezdomnych, chorych, opuszczonych, rodzin wielodzietnych bez wystarczających środków do życia i wychowywania dzieci ${ }^{17}$.

O konieczności świadczenia miłosierdzia i działalności charytatywnej wspominają również dokumenty Magisterium w Polsce. II Polski Synod Plenarny wzywa, aby szczególną troską duszpasterską objąć osoby starsze, zwłaszcza samotne i chore, przeżywające ciężar samotności psychicznej i fizycznej, doświadczające cierpień spowodowanych chorobą, ubytkiem sił, poczuciem zbliżenia się końca życia. Synod apeluje, aby powoływać w parafiach kluby trzeciego wieku i podobne wspólnoty, a także ukazywać tym osobom sens obecności we wspólnocie Kościoła, wykorzystując ich potencjał duchowy, który mogą wnieść w życie wspólnoty Ludu Bożego ${ }^{18}$. Synod wzywa o zadbanie odpowiedniej liczby miejsc dla chorych i starszych w kościołach, o stosowne konfesjonały dla osób słabo słyszących, a także o stworzenie odpowiednich podjazdów i wejść dla osób nie mogących poruszać się bez wózka inwalidzkiego ${ }^{19}$.

W pracy apostolskiej Kościoła mają być wykorzystywane mass media. Trzeba utrzymywać i wspierać prasę oraz wydawnictwa katolickie, filmy, radio i telewizję (DSP 3; 13; 17), odpowiednio formując, szczególnie młodzież i dzieci, do odbioru przekazu medialnego (DSP 9-11; 16). Media, będąc pierwszym areopagiem wspótczesnych czasów, mają być narzędziami w służbie prowadzonej przez Kościół ewangelizacji i nowej ewangelizacji współczesnego świata

${ }^{16}$ B e nedykt XVI do biskupów polskich. Przemówienie do trzeciej grupy biskupów (Watykan, 17 XII 2005). Poznań 2005 s. 32-33.

${ }^{17}$ Franciszek do biskupów polskich przebywających w Watykanie $\mathrm{z}$ wizytą ad limina Apostolorum (Watykan, 7 II 2014), http://www.diecezja.wloclawek.pl/pl/news/20,aktualnosci/ 1306,watykan-przeslanie-papieza-franciszka-do-polskich-biskupow-odbywajacych-wizyte-adlimina-apostolorum (Odczyt: 16.08.2014).

${ }^{18}$ Powołanie do życia w matżeństwie i rodzinie, $\mathrm{nr} 48$, dz. cyt.

${ }^{19}$ Tamże, nr 139. 
(RM 37; CP 126; AEN 11). W sposób szczególny potrzeba wykorzystać w pracy duszpasterskiej Kościoła Internet, który chociaż nie może stać się zamiennikiem prawdziwej wspólnoty ludzkiej, wcielonej rzeczywistości sakramentów i liturgii, może ją uzupetniać, przyciagać ludzi do petniejszego doświadczenia wiary i ubogacać religijne życie korzystajacych $z$ niego osób ${ }^{20}$. Nowa przestrzeń cybernetyczna jest dla Kościoła wezwaniem do posługiwania się nią w głoszeniu ewangelicznego orędzia ${ }^{21}$. Ewangelizacja wymaga zainteresowania środkami komunikacji społecznej, szczególnie nowymi mediami, w których spotykają się ludzie, stawiając liczne pytania, kształtując tam często swoje sumienia ${ }^{22}$. Wśród zagadnień podejmowanych w pracy duszpasterskiej Kościoła w czasopismach i na stronach internetowych diecezji powinna się znaleźć szeroko rozumiana tematyka eucharystyczna (RE 34).

Benedykt XVI, w przemowie do pierwszej grupy biskupów polskich przebywających w Watykanie z wizytą ad limina Apostolorum w 2005 r., zwracał uwagę na konieczność wykorzystywania lokalnych, regionalnych i ogólnopolskich środków społecznego przekazu w dziele ewangelizacji kultury oraz nowej ewangelizacji. W sposób szczególny odnosząc się do parafialnej prasy katolickiej, która przyczynia się do szerzenia kultury prawdy, dobra i piękna, papież apelował o podnoszenie jej poziomu i zwiększania zakresu jej oddziaływania ${ }^{23}$.

O roli mediów w duszpasterstwie oraz formacji do właściwego korzystania z nich mówią dokumenty II Polskiego Synodu Plenarnego, podkreślając, że cały Kościół powinien w posłudze duszpasterskiej i katechetycznej posługiwać się własną prasą, rozgłośnią radiową i Internetem ${ }^{24}$. Synod podkreśla, że w obliczu postępującej „cywilizacji obrazu”, należy popierać rozwój prasy katolickiej, powiększając zasięg jej oddziaływania, zachęcając zarazem do jej czytania, co powinno stać się ważnym zadaniem posługi duszpasterskiej w każdej parafii. Trzeba też z życzliwością odnieść się do inicjatyw zakładania pisma parafialnego ${ }^{25}$. W czasopismach katolickich, które mają odznaczać się wysokim poziomem merytorycznym oraz warsztatowym i redaktorskim, powinny znaleźć się publikacje

\footnotetext{
${ }^{20}$ Papieska Rada ds. Środków Społecznego Przekazu: Kościół a Internet (Watykan, 22 II 2002) $\mathrm{nr} 5$, www.opoka.org.pl/biblioteka/W/WR/rady_pontyfikalne/r_komunik_spol/kosciol internet_22022002.html (data pobrania: 26.12.2012)

${ }^{21} \mathrm{~J}$ a n P a w eł I I: Orędzie na 36 Światowy Dzień Środków Społecznego Przekazu Internet nowym forum dla gloszenia Ewangelii (Watykan, 24 I 2002), $\mathrm{nr} 3$, http:// www. opoka.org.pl/biblioteka /W/WP/jan_pawel_ii/przemowienia/internet_aut_12052002. html (Odczyt: 3.11.2012).

${ }^{22}$ Orędzie końcowe XIII Synodu Biskupów do ludu Bożego Ewangelia w świecie. „L'Osservatore Romano”. Wydanie polskie. R. 2012 nr 12 pkt 10.

${ }^{23} \mathrm{~B}$ e n e d y k t X V I do biskupów polskich. Przemówienie do pierwszej grupy biskupów (Watykan, 26 XI 2005), dz. cyt., s. 12.

${ }^{24}$ Ewangelizacja kultury $i$ środków społecznego przekazu, nr 86, dz. cyt.

${ }^{25}$ Tamże.
} 
uczące postawy miłości, modlitwy i zwyczajów katolickich (...), prezentowania możliwości godziwej rozrywki i wypoczynku ${ }^{26}$. Kościół powinien także dostrzegać możliwości Internetu, zakładając i odnawiając katolickie strony, wykorzystując je do głoszenia Dobrej Nowiny ${ }^{27}$.

W nauczaniu Magisterium, zarówno na poziomie Kościoła powszechnego, jak i lokalnego w Polsce, znajduje się dużo wskazań dotyczących świętowania niedzieli przez katolików. O ile zasadniczo wiadomym jest, jak ma ono wyglądać w aspekcie wertykalnym (uczestnictwo we mszy św. i inne formy religijności), to często wielu $\mathrm{z}$ nich nie zna gruntownie jego przesłania dotyczącego aspektu horyzontalnego, a co za tym idzie, nie stosuje go w praktyce codziennego życia. Trzeba upowszechniać jego znajomość, pokazując, co składa się na realizację III przykazania Dekalogu - Pamiętaj, abyś dzień święty święcit.

\section{Sposoby przeżywania niedzielnego czasu wolnego przez Polaków}

Mając świadomość, jak katolicy powinni przeżywać niedzielę w wymiarze horyzontalnym, odwołując się do wyników własnych badań, spróbujemy ukazać, w jaki sposób Polacy realizują omówiony wzorzec teologiczny ${ }^{28}$. Dla poszerzenia perspektywy badawczej przytoczymy także wyniki innych badań realizowanych w Polsce.

Mówiąc o różnorodnych sposobach przeżywania niedzieli, należy najpierw odwołać się do wyników badań dotyczących świadomości tego dnia. Rzutuje ona na podejmowane działania, nadając im określony kształt. Chcąc zbadać świadomość respondentów dotyczącą istoty dnia Pańskiego, autor postawił pytanie otwarte: Czym dla Pana(i) jest niedziela? Na tak postawione pytanie największy procent badanych respondentów (41,9\%) odpowiadał, że jest to dla nich dzień odpoczynku. Na drugim miejscu pojawiła się opinia, że niedziela to dzień spotkań $z$ rodzina $(34,9 \%)$. Następnie respondenci podkreślali, iż niedziela jest dla nich dniem świętym (22,6\%), dniem uczestnictwa we mszy św. (19,8\%), dniem poświęconym Bogu (11,3\%), dniem bez pracy $(9,1 \%)$, dniem spotkania z Bogiem $(8,7 \%)$. Podając sposób rozumienia istoty niedzieli, 34,9\% respondentów wymieniało jeszcze inne określenia: centrum tygodnia, dzień lektury Biblii, dzień lektury prasy katolickiej, dzień jak inny, dzień modlitwy, dzień nauki, dzień nudy,

${ }^{26}$ Tamże, nr 87.

${ }^{27}$ Tamże, nr 90.

${ }^{28}$ Autor w okresie od maja do sierpnia 2009 roku przeprowadził badania wśród katolików w Polsce ze 100. losowo wybranych parafii 4 diecezji. Pod uwagę wzięto diecezje o najwyższym (diecezja tarnowska) i jednym z najniższych wskaźników dominicantes (archidiecezja szczecińskokamieńska) oraz archidiecezję warszawską i diecezję warszawsko-praską, w których wskaźnik dominicantes kształtuje się na poziomie średnim. Wiernym w wybranych parafiach rozdano 2000 ankiet, z których otrzymano 819, z czego do dalszej analizy zakwalifikowano 797. 
dzień bez szkoty, dzień dobrych uczynków, dzień pogłębiania wiary religijnej, dzień pracy, dzień radości, dzień refleksji, dzień rozmowy z Bogiem, dzień rozrywki, dzień wyciszenia, ostatni dzień weekendu, pamiątka zmartwychwstania, pierwszy dzień tygodnia, siódmy dzień tygodnia, wyciszenie.

Warto zauważyć, że w określeniach istoty niedzieli, podawanych przez respondentów, przeplatały się jej dwa wymiary: sakralny i świecki. Z badań wynika, że na pierwszy plan wybijał się bardziej wymiar świecki. Godnym podkreślenia wydaje się fakt, że wśród podawanych świeckich określeń niedzieli, badani respondenci wymieniali różne formy jej świętowania polecane przez Magisterium, co może świadczyć nie tyle o dobrej znajomości jego nauczania, ile o kierowaniu się pewnymi intuicjami oraz wzorcami jej przeżywania wyniesionymi być może $\mathrm{z}$ domu rodzinnego albo $\mathrm{z}$ innych źródeł. Trzeba jednak zauważyć, że w świadomości niektórych badanych niedziela nie jest pojmowana jako wyróżniający się spośród innych dzień tygodnia (dzień jak inny, dzień nauki, dzień pracy, ostatni dzień weekendu), co świadczy o braku zrozumienia jego istoty. Niektóre określenia (dzień nudy) sugerują także, że u części respondentów brakuje pomysłów na jego przeżywanie, co zarówno domaga się podjęcia właściwych działań formacyjnych, jak i propagowania wzorów świętowania.

Niedziela powinna być czasem odpoczynku, a nie pracy zarobkowej. Autor w swoich badaniach zapytał respondentów o podejmowanie pracy zarobkowej w tym dniu. Uzyskane wyniki badań prezentuje diagram $\mathrm{nr} 1$.

$\mathrm{Z}$ diagramu 1 . wynika, że $66,5 \%$ respondentów nie pracuje zawodowo $\mathrm{w}$ niedzielę, $10,7 \%$ pracuje okazjonalnie, natomiast tylko $7,4 \%$ pracuje $\mathrm{w}$ większość niedziel. 12,9\% respondentów stwierdziło, że są osobami bezrobotnymi, a 2,5\% badanych nie udzieliło odpowiedzi. $Z$ kolei badania CBOS przeprowadzone w 2010 r. wykazały, że 35,0\% ogółu respondentów, a w grupie pracujących aż $64,0 \%$, odpowiedziało twierdząco na pytanie dotyczące podejmowania stałej lub dorywczej pracy zarobkowej w soboty i niedziele ${ }^{29}$. Z jednej strony należy wyrazić zadowolenie $\mathrm{z}$ dużego procentu respondentów, którzy rozumieją rolę odpoczynku należnego człowiekowi ze względu na jego ludzką godność i związane z tym potrzeby religijne, rodzinne, kulturowe oraz społeczne. Badani respondenci, którzy w większości są regularnie praktykującymi katolikami, systematycznie uczestniczącymi we mszy św. niedzielnej, dobrze rozumieją znaczenie odpoczynku, wpisanego razem $\mathrm{z}$ cyklem pracy w naturę ludzką, pozwalając człowiekowi wyrywać się z rytmu ziemskich zajęć. Warto jednak postawić pytanie o motywy pracy w niedzielę tych Polaków, którzy podejmują takie działanie. Czy jest to spowodowane ich złą sytuacją materialną, tak że muszą dorabiać w tych dniach, aby zapewnić sobie i swojej rodzinie właściwy

\footnotetext{
${ }^{29}$ A. S t a s i k: Czas wolny Polaków. Komunikat z badań. Warszawa 2010 s. 1- 8.
} 
status życia, czy też są owładnięci duchem konsumpcjonizmu, przedkładając mieć nad być?

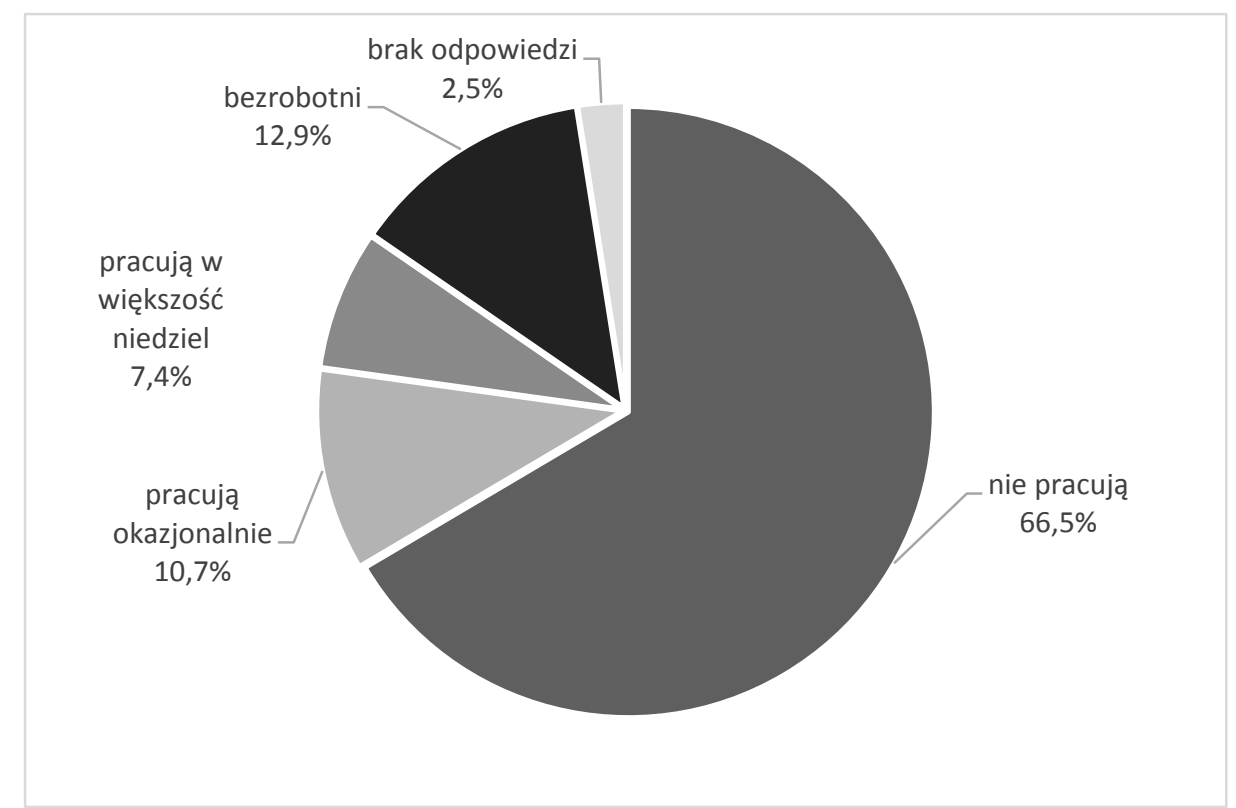

Diagram 1. Podejmowanie pracy zawodowej przez respondentów w niedzielę.

Kolejną kwestią, podjętą przez autora w prowadzonych badaniach, był najczęstszy sposób odpoczywania Polaków w niedzielę. Uzyskane wyniki badań zawiera wykres nr 1 .

Z wykresu 1. wynika, że respondenci zwykle i dość często odwiedzają rodzinę i przyjaciół, bądź przyjmują ich u siebie $-48,8 \%$, czytają prasę i książki $45,6 \%$, oglądają telewizję - 42,9\%, spacerują - 39,2\%, wyjeżdżają na łono natury i wycieczki krajoznawcze $-24,1 \%$, rozwijają swoje hobby $-14,3 \%$, odsypiają zaległości - 12,4\%, robią zakupy - 3,3\%, chodzą do kina, teatru i na mecze $3,2 \%$, ,imprezują" - 1,9\%. 11,0\% respondentów deklaruje, że robi jeszcze inne rzeczy. Z kolei największe wskaźniki procentowe odpowiedzi nigdy pojawiły się w związku z chodzeniem do kina, teatru lub na mecze (45,3\%), ,imprezowaniu" $(44,9 \%)$, odsypianiu zaległości $(33,4 \%)$, robieniu zakupów $(32,9 \%)$, rozwijaniu hobby $(26,5 \%)$. Jeżeli chodzi o kategorię czasami, wskaźnik odpowiedzi kształtuje się w przedziale od $34,4 \%$ (chodzenie do kina, teatru i na mecze) do 50,1\% (wyjazdy na łono natury i wycieczki krajoznawcze). 


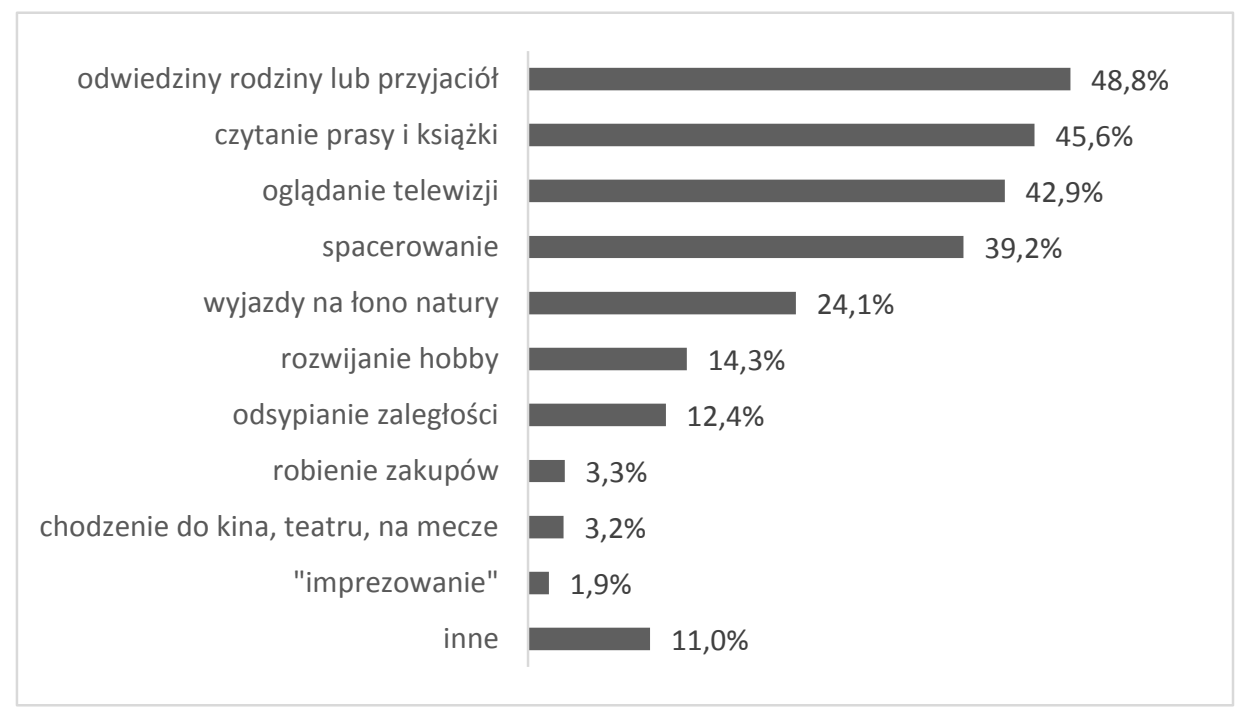

Wykres 1. Najczęstsze sposoby odpoczynku Polaków w niedzielę.

Jak widać z przytoczonych danych, najczęstszą formą odpoczynku niedzielnego respondentów są spotkania z rodziną i przyjaciółmi, lektura prasy i książek oraz oglądanie telewizji ${ }^{30}$. Tylko niewielki procent badanych robi zwykle i dosyć często w niedziele zakupy. Na podkreślenie zasługuje wysoki wskaźnik osób czytających prasę i książki, co znaczenie odbiega od obrazu statystycznego Polaka zasadniczo nie czytającego książek ${ }^{31}$. Respondenci sporadycznie korzystają $\mathrm{z}$ różnych form niedzielnego wypoczynku. $\mathrm{Z}$ badań wynika, że tylko $3,2 \%$ respondentów uczęszcza do kina, teatru i na mecze. Przyczyn tego można doszukiwać się w braku odpowiednich funduszy, nierozbudzonych potrzebach lub zbyt dużej odległości do miejsc, w których odbywają się tego typu wydarzenia.

Warto zestawić powyższe badania $\mathrm{z}$ badaniami przeprowadzonych przez CBOS w 2010 roku (wykres nr 2), z których wynika, że jeżeli chodzi o sposób

${ }^{30}$ Wspomniana tendencja jest zbieżna z badaniami prowadzonymi przez Krajową Radę Radiofonii. W I kwartale 2013 r. statystyczny Polak oglądał telewizję przez 4 godziny 41 minut dziennie, tj. o 10 minut dłużej niż w analogicznym okresie roku ubiegłego. Według Rady powyższe zjawisko należy między innymi wiązać z rosnącym zasięgiem naziemnej telewizji cyfrowej.

Zob. Krajowa Rada Radiofonii i Telewizji: Rynek telewizyjny w 1 kwartale $2013 \mathrm{r}$. Warszawa 2013, http://www.krrit.gov.p1/Data/Files/_public/Portals/0/regulacje-prawne/polska/kontrolanadawcow/rynek-telewizyjny-w-i-kwartale-2013.pdf (Odczyt: 17.07.2013).

${ }^{31}$ Ogólnopolskie badania czytelnictwa przeprowadzone przez Bibliotekę Narodową i TNS OBOP pokazują, że $60,8 \%$ Polaków nie przeczytało w 2012 roku żadnej książki.

Zob. Zob. R. Ch y mk ow ski, I. K or y ś, O. D a w i d ow i c z-Ch y m k ow s k a: Spoteczny zasięg ksiązki w Polsce w 2012 r., http://www.bn.org.pl/aktualnosci/501-czytelnictwopolakow-w-2012-r.-\%E2\%80\%93-wyniki-badan.html (Odczyt: 17.07.2013). 
spędzania wolnego czasu w sobotę i niedzielę, to ponad połowa badanych Polaków ogląda telewizję (52,0\%). Do kolejnych wskazanych czynności należą: życie rodzinne $(36,0 \%)$, leżenie i odpoczywanie $(27,0 \%)$, chodzenie na spacery $(24,0 \%)$, wysypianie się $(22,0 \%)$, spotkania $\mathrm{z}$ krewnymi i przyjaciółmi i wykonywanie zaległych prac w domu $(21,0 \%)$, chodzenie do kościoła i modlitwa $(19,0 \%)$, czytanie książek $(18,0 \%)$, gazet i tygodników $(17,0 \%)$, wyjeżdżanie na wycieczki za miasto (13,0\%). Tylko $7,0 \%$ badanych spędza czas wolny $\mathrm{w}$ kinie, teatrze, na koncercie lub wystawie ${ }^{32}$.

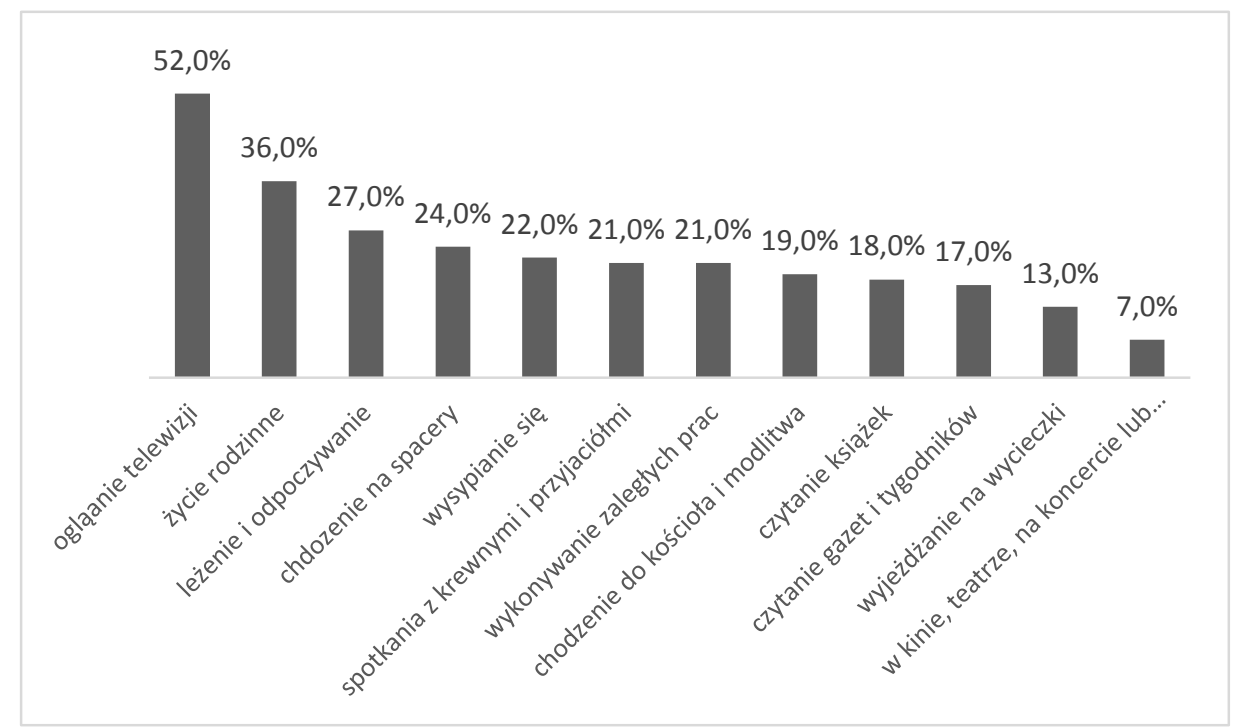

Wykres 2. Sposób spędzania czasu wolnego Polaków w sobotę i niedzielę. [Źródło: CBOS]

Polacy zasadniczo odpoczywają biernie oglądając telewizję. Przywiązują duże znaczenie do prowadzenia życia rodzinnego. W zbyt małym stopniu czytają, wyjeżdżają na wycieczki krajoznawcze i korzystają z dóbr kultury. Potrzeba podejmowania różnych sposobów działań, aby aktywizować ich do bardziej czynnego odpoczynku, przyczyniającego się do wszechstronnego rozwoju.

Dokumenty Magisterium wskazują na konieczność realizowania przez parafię nie tylko funkcji religijnych, ale również pozareligijnych. Szukając odpowiedzi na pytanie, czy to nauczanie znajduje odzwierciedlenie w polskiej rzeczywistości, autor w swoich badaniach zapytał respondentów, czy w domu parafialnym przy ich kościele jest możliwość wspólnego przeżywania czasu w niedzielę. Wyniki badań zostały przedstawione $\mathrm{w}$ diagramie $\mathrm{nr} 2$.

${ }^{32}$ A. S t a s i k: Czas wolny Polaków. Komunikat z badań, dz. cyt., s. 1-8. 


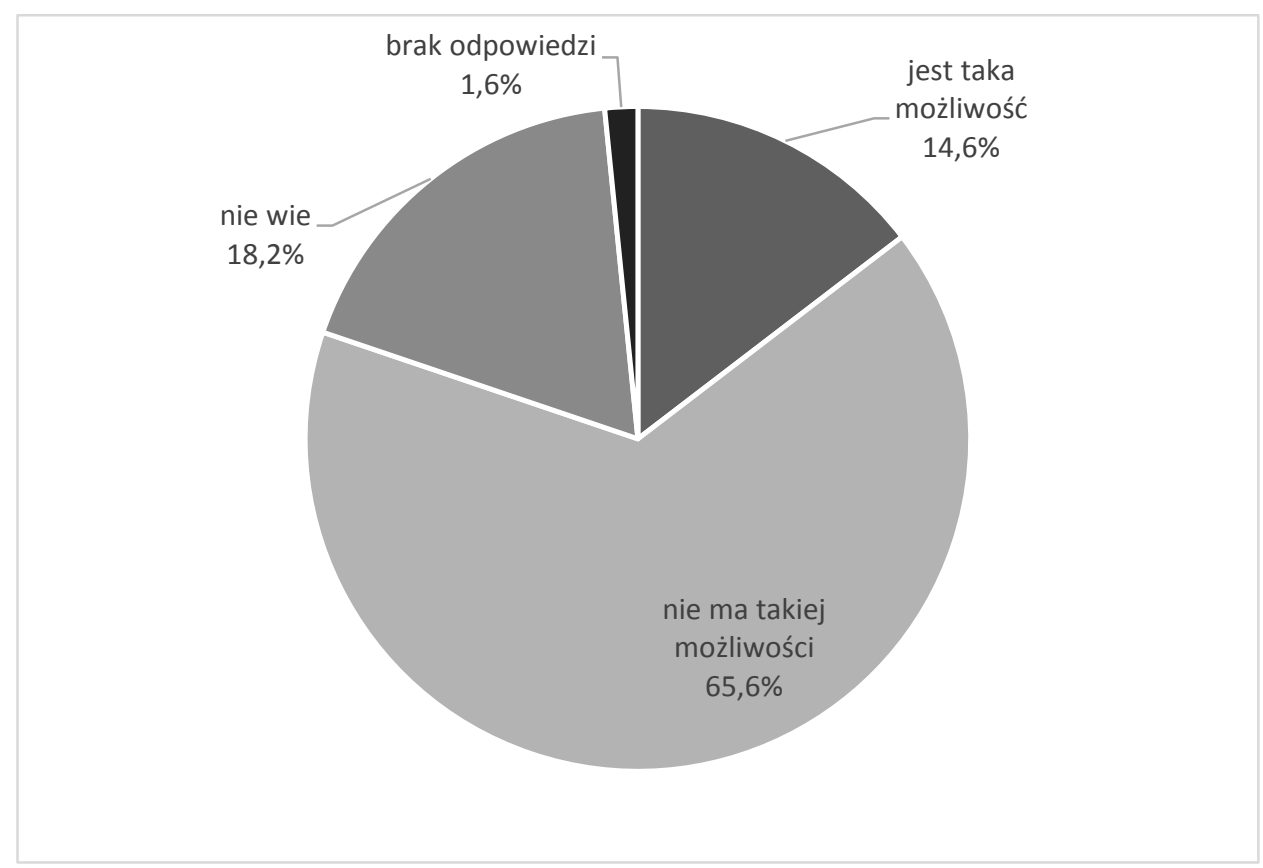

Diagram 2. Możliwość spędzania wolnego czasu w niedzielę w parafiach respondentów.

$\mathrm{Z}$ diagramu 2. wynika, że tylko $14,6 \%$ respondentów odpowiedziało twierdząco na to pytanie, natomiast aż $65,6 \%$ badanych nie zauważyło takiej możliwości. $18,2 \%$ nic nie wiedziało na ten temat. Nie udzieliło odpowiedzi $1,6 \%$ respondentów. Jeżeli chodzi o osoby twierdzące, że ich parafie nie stwarzają możliwości wspólnego przeżywania czasu w niedzielę, to zauważa się pewne zróżnicowanie wskaźników w strukturze zamieszkania. O tym, że nie ma możliwości wspólnego przeżywania czasu wolnego w ich parafiach, twierdzą częściej mieszkańcy wsi $(81,7 \%)$ i średnich miast $(71,2 \%)$. Inaczej ta sprawa postrzegana jest przez mieszkańców dużych $(58,5 \%)$ i małych miast $(52,4 \%)$. Koniecznym jest, w obliczu przedstawionych wyników, podjęcie działań, które sprawią, że parafia oprócz swojej podstawowej funkcji religijnej, będzie też pełniła funkcję kulturotwórczą.

Autor zapytał też respondentów, jakie są ich oczekiwania wobec swoich parafii odnośnie do spędzania wolnego czasu w niedziele. Wyniki badań zawiera wykres nr 3. 


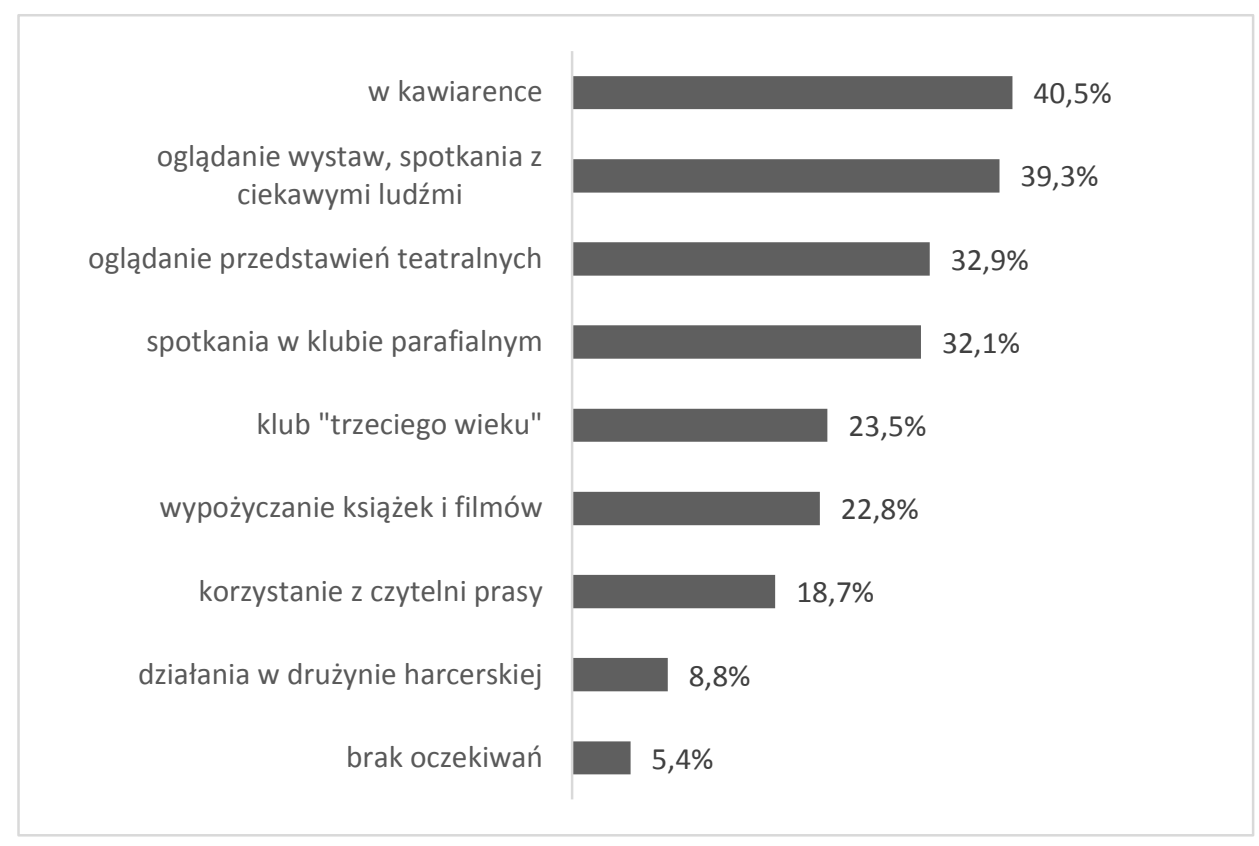

Wykres 3. Oczekiwania respondentów dotyczące form spędzania czasu wolnego $w$ niedziele $w$ swojej parafii.

$\mathrm{Z}$ wykresu 3. wynika, że badani respondenci najbardziej oczekują możliwości spędzenia wolnego czasu w tym dniu w kawiarence parafialnej - 40,5\%, oglądania wystaw, spotkań się z artystami, pisarzami i ciekawymi ludźmi $39,3 \%$, oglądania przedstawień teatralnych $-32,9 \%$, spotykania się w klubie parafialnym - 32,1\%, klubie „trzeciego wieku” - 23,5\%, możliwości wypożyczania książek i filmów $-22,8 \%$, korzystania z czytelni prasy $-18,7 \%$, działania w drużynie harcerskiej $-8,8 \%{ }^{33}$. Tylko $5,4 \%$ respondentów nie ma wobec parafii żadnych oczekiwań dotyczących tej kwestii.

Przytoczone wyniki badań wskazują na szerokie oczekiwania respondentów wobec parafii w aspekcie spędzania czasu wolnego w niedzielę. Nie zapominając o podstawowych funkcjach parafii, do których należy przede wszystkim niedzielna celebracja Eucharystii służąca budowaniu wspólnoty (zob. DD 35), trzeba zwrócić uwagę na fakt, że powinna ona stawać się domem rodzinnym, gościnnym, braterskim, który w obliczu zachodzących głębokich procesów rozkładu ludzkich społeczności i ich dehumanizacji zaspokoi pragnienie ludzi związane z budowaniem jedności (zob. ChL 26-27). Mimo przeżywanych kryzysów, parafia pozostaje pierwszą wspólnotą kościelną, w której jest realizowana zarówno działalność duszpasterska, jak i społeczna. Proponowane przez nią różne

\footnotetext{
${ }^{33}$ Wypowiedzi nie sumują się do 100,0\%, gdyż respondenci mogli wybrać kilka wypowiedzi.
} 
formy spędzania wolnego czasu $\mathrm{w}$ niedzielę mogą $\mathrm{z}$ powodzeniem służyć temu celowi ${ }^{34}$.

Jan Paweł II podkreśla, że jednym z problemów współczesnego świata jest zatracenie pierwotnego sensu niedzieli przez wielu chrześcijan, wyrażającym się zarówno zaniedbywaniem uczestnictwa w niedzielnej Eucharystii, jak również nieumiejętnością świętowania, którego przejawem jest nie powstrzymywanie się od prac i zajęć niezgodnych z istotą tego dnia (zob. DD 4; 67). Do takich zajęć można z pewnością zaliczyć robienie zakupów. Autor zapytał swoich respondentów czy podejmują taką czynność w niedziele. Uzyskane wyniki badań zawiera diagram $n r 3$.

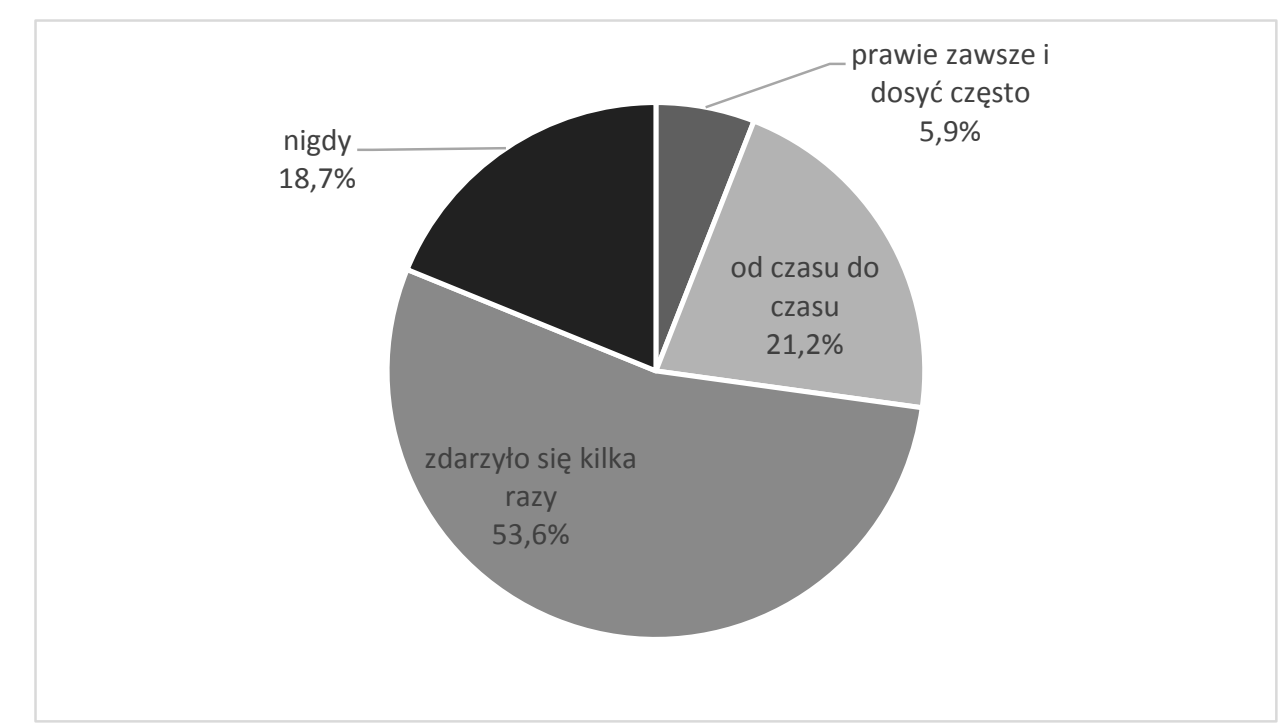

Diagram 3. Robienie zakupów w niedzielę przez respondentów.

$\mathrm{Z}$ badań wynika, że prawie zawsze $i$ dosyć często robi zakupy w niedzielę $5,9 \%$ respondentów, od czasu do czasu $21,1 \%$ badanych, zdarzyto się to kilka razy 53,6\% ankietowanym, a nigdy nie robi zakupów $18,7 \%$.

A jak wygląda kwestia robienia zakupów przez Polaków w niedzielę w świetle badań innych ośrodków badawczych? Z cyklicznych badań CBOS dotyczących robienia przez Polaków zakupów w niedzielę, przeprowadzonych w latach 1997, 2002, 2004, 2008 i 2010 wynika, że jeżeli chodzi o osoby często robiące zakupy w niedziele, to wskaźnik procentowy tych osób utrzymuje się od 2002 roku zasadniczo na tym samym poziomie, wynosząc $7,0 \%$. Wyjątek stanowił rok

${ }^{34}$ J a n P a w e 1 I I: Parafia - wspólnota otwarta. Przemówienie dla uczestników sesji plenarnej Kongregacji Duchowieństwa. „L'Osservatore Romano”. Wydanie polskie. R. 1984 nr $11-12$ s. 24. 
2004, w którym ten wskaźnik wyniósł $12,0 \%$. W miarę na tym samym poziomie utrzymuje się wskaźnik procentowy osób robiących czasami zakupy w niedzielę, wahając się od $27,0 \%$ do $30,0 \%$. Wskaźnik osób robiących sporadycznie zakupy w niedzielę, po pewnym wzroście w latach 2002-2008, obniżył się do poziomu $28,0 \%$. W porównaniu z badaniami prowadzonymi w $2008 \mathrm{r}$. Dwa lata później, w 2010 r., o dziewięć punktów procentowych spadła liczba respondentów robiących zakupy w niedziele (z 71,0\% do 62,0\%). O tyle samo wzrosła liczba osób deklarujących, że nigdy nie robi zakupów w tym dniu ${ }^{35}$. $Z$ kolei badania prowadzone przez Instytut Badania Rynku Pentor pokazują, że Polacy stosunkowo rzadko dokonują zakupów w niedzielę. Z badań zrealizowanych w 2006 r. wynika, że 39,0\% respondentów deklaruje, iż nigdy nie robi zakupów w niedziele, $45,0 \%$ przyznaje, że robi je rzadko (raz na miesiąc lub rzadziej), a 15,0\% respondentów twierdzi, że robi je zawsze w niedziele lub 2-3 razy w miesiącu. Na pytanie dotyczące tego, gdzie respondenci spędzaliby czas w niedzielę, gdyby sklepy nie były otwarte, $49,0 \%$ badanych stwierdziło, że na spotkaniach z rodziną i znajomymi $^{36}$. Badania prowadzone przez ten sam Instytut w $2010 \mathrm{r}$. wykazały, że obecnie tylko 2,0\% Polaków chodzi na wielkie zakupy w niedzielę. Zasadniczo robią oni zakupy w piątki i soboty. Instytut podkreśla, że powyższa tendencja utrzymuje się od trzech lat ${ }^{37}$.

W debacie publicznej prowadzonej w Polsce pojawiają się propozycje zakazu handlu w dni świąteczne i niedziele. Obrońcy niedzieli rozumianej jako najstarsze przykazanie socjalne świata postulują, aby na wzór Niemiec wprowadzić konstytucyjny zakaz handlu w każdą niedzielę ${ }^{38}$. Jak zatem do prawnego zakazu handlu w niedziele odnoszą się respondenci, z którymi rozmawiał autor? Wyniki badań zawiera diagram $\mathrm{nr} 4$.

${ }^{35} \mathrm{~K}$. W ą d oło w s k a: Mania kupowania czyli o postawach konsumenckich Polaków. Komunikat z badań. Warszawa 2011 s. 12.

${ }^{36}$ Instytut Badania Rynku Pentor: Stosunek Polaków do handlu w niedzielę. Warszawa 2006 www.pentor.pl/main.xml (Odczyt: 28.09.2010).

${ }^{37}$ Zakaz handlu w niedzielę. Projekt ustawy NSZZ ,Solidarność" - www.eporady24pl/zakaz handlu w niedzielę-projektustawynszzasolidarność-aktualności,1339.html (Odczyt: 24.09.2010).

${ }^{38} \mathrm{~W}$ Niemczech wysiłki różnych środowisk (grup interesu, organizacji pozarządowych, związków zawodowych i kościołów chrześcijańskich) doprowadziły do tego, że artykuł 140. niemieckiej ustawy konstytucyjnej stanowi: niedziela jest dniem odpoczynku i duchowego wytchnienia. 


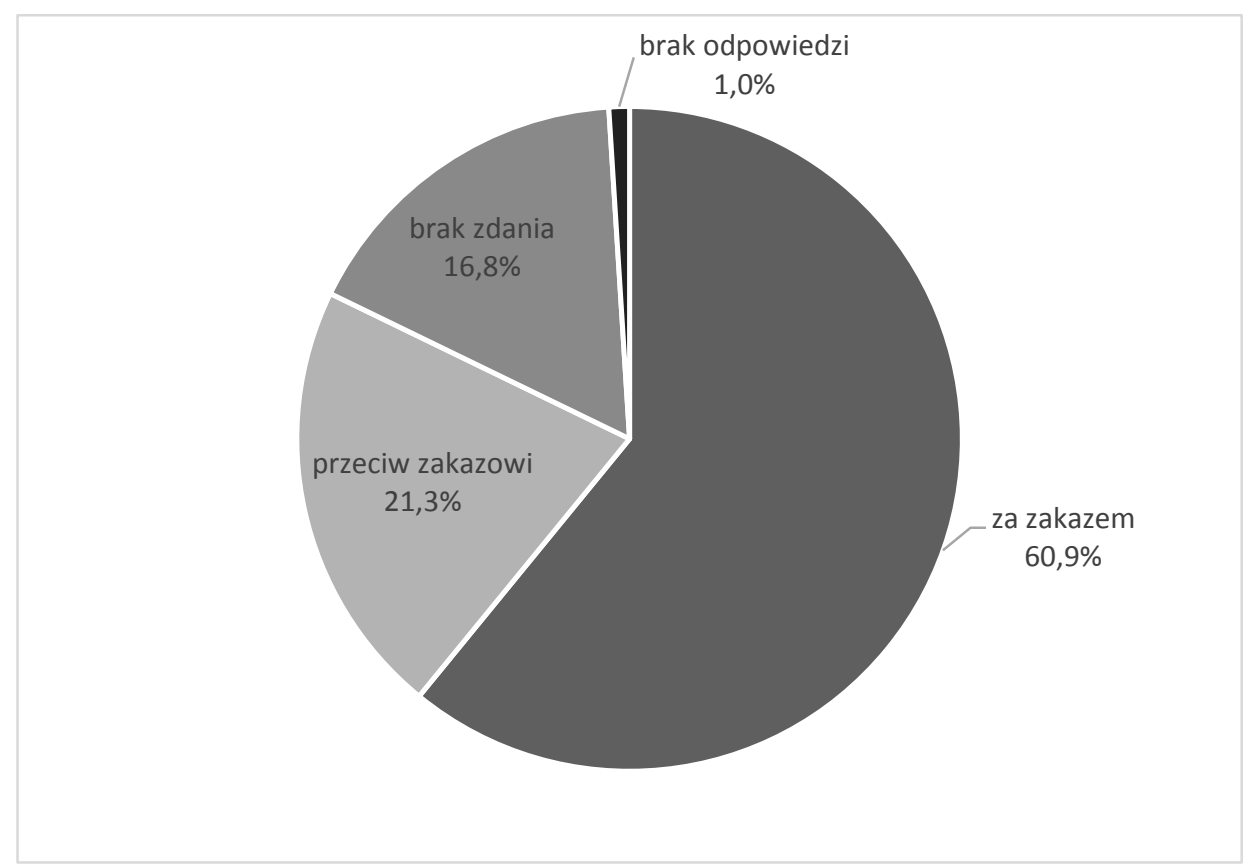

Diagram 4. Stosunek respondentów do zakazu handlu w niedzielę.

$\mathrm{Z}$ diagramu 4. wynika, że o konieczności takiego zakazu wspomina $60,9 \%$ badanych respondentów, przeciwnych takim rozwiązaniom jest $21,3 \%$ badanych, a nie ma zdania $16,8 \%$ populacji. Nie udzieliło odpowiedzi $1,0 \%$ badanych. Należy zastanowić się nad tym, dlaczego prawie jedna czwarta respondentów występuje przeciwko takiemu zakazowi i jakie warto podjąć działania, aby ich przekonać do zmiany postawy. Takie samo pytanie należy postawić $\mathrm{w}$ aspekcie działań prowadzonych wobec osób nie mających zdania na poruszany temat.

Warto zapytać, jak wygląda powyższa kwestia w świetle badań innych instytutów badawczych? Cytowane już badania Pentora z 2010 r. pokazują, że 3/4 Polaków jest za zakazem handlu $\mathrm{w}$ niedzielę ${ }^{39}$. Z kolei badania prowadzone w 2013 r. przez MillwardBrown SMG/KRC pokazują, że 30,0\% Polaków zdecydowanie popiera wprowadzenie zakazu handlu w niedzielę, a 17,0\% raczej popiera wprowadzenie takiego zakazu. Liczba przeciwników wprowadzenia zakazu handlu w niedzielę jest nieco większa - zdecydowanie sprzeciwia się temu $30,0 \%$ Polaków, a raczej sprzeciwia się 19,0\% respondentów. Z badań wynika,

${ }^{39}$ Zakaz handlu w niedzielę. Projekt ustawy NSZZ ,, Solidarność”, dz. cyt. 
że liczba zwolenników i przeciwników handlu w niedzielę utrzymuje się mniej więcej na tym samym poziomie ${ }^{40}$.

Jednym z owoców uczestnictwa w niedzielnej mszy św. powinno być wielorakie zaangażowanie charytatywne (por. DD 69; 72). Autor zapytał swoich respondentów o to, jak wygląda ich niedzielne zaangażowanie charytatywne. Wyniki badań zawiera diagram $\mathrm{nr} 5$.

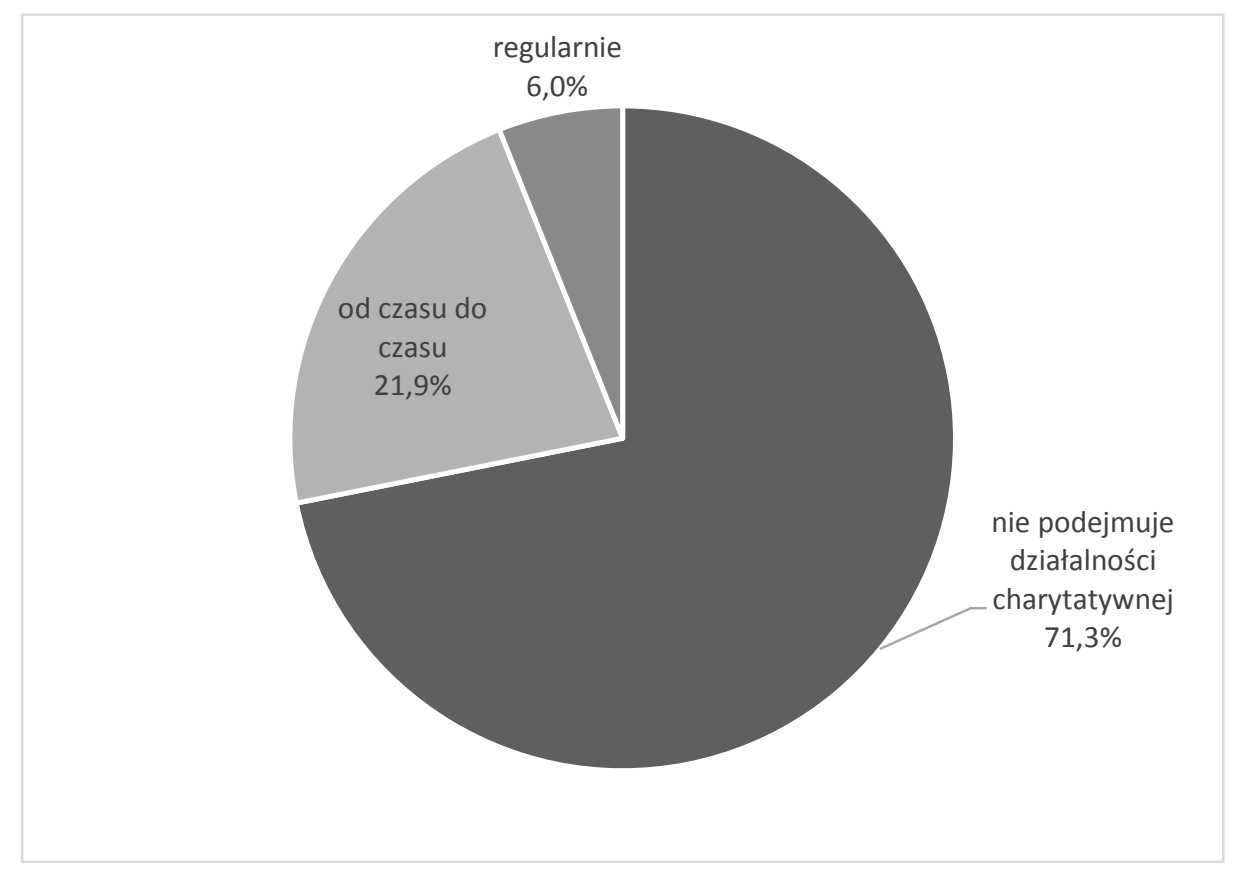

\section{Diagram 5. Podejmowanie przez respondentów} działalności charytatywnej w niedzielę.

$Z$ diagramu 5. wynika, że, aż 71,3\% respondentów nie podejmuje działalności charytatywnej w niedzielę, $21,9 \%$ czyni to od czasu do czasu, a tylko $6,0 \%$ w sposób regularny. Warto podjąć refleksję nad przyczyną widocznego prawie $\mathrm{u}$ trzech czwartych badanych zaangażowania charytatywnego w niedzielę Może angażują się oni w taką działalność w innych dnia tygodnia, co nie wykluczałoby podjęcia pewnych działań także w niedzielę.

Z badań prowadzonych wśród Polaków wyłania się zróżnicowany obraz przeżywania przez nich czasu świątecznego. Mając więcej czasu wolnego, cenią

${ }^{40}$ Arb, Niemal co drugi Polak popiera zakaz handlu w niedziele - www.wprost.p1/ar/402038/ Niemal-co-drugi-Polak-popiera-zakaz-handlu-w-niedziel/?utm_source=feedburner\&utm_medium =feed\&utm_campaign=Feed $\% 3 \mathrm{~A}+$ wprost-gospodarka+\%28Wydarzenia $+\mathrm{W} p r o s t+24 \% 3 \mathrm{~A}+\mathrm{Gosp}$ odarka\%29 (Odczyt: 12.09.2013). 
sobie jego wartość, przeżywając go w bardzo zróżnicowany sposób. Część Polaków pracuje w niedziele, co raczej nie dotyczy osób podejmujących regularną praktykę uczestnictwa w Eucharystii. Większość Polaków nie robi większych zakupów w niedzielę, często opowiadając się zarazem za zakazem handlu w tym dniu. Może widoczna w niedzielę duża liczba osób w hipermarketach nie jest tylko wyrazem rozwijającej się kultury konsumpcyjnej, ale także jednym z przejawów pragnienia wspólnego przeżywania czasu wolnego, na którą to potrzebę nie odpowiadają $\mathrm{w}$ dostateczny sposób polskie parafie. Polacy spędzają czas wolny raczej biernie.

Wydaje się, że dobrym podsumowaniem tej części artykułu, ukazującej sposoby świętowania niedzieli przez katolików w Polsce w wymiarze horyzontalnym, będzie przywołanie wyników badań CBOS z 2010 r., wskazujących na wzrastające przyzwolenie na desakralizację czas świątecznego ${ }^{41}$. W porównaniu z 2002 r. zauważa się zwiększający się stopień aprobaty różnych zachowań, obejmujących wielorakie aspekty świętowania. Przykładowo, zmiany oceny zachowań zauważa się w kwestiach: zajmowania się w niedziele lub święta kościelne pracami remontowymi lub porządkowymi w domu (odpowiednio 4,74$3,96)^{42}$, niechodzenia do kościoła w niedziele i święta $(3,22-2,60)$, dobrowolnej pracy zarobkowej lub dorabiania w niedziele $(3,01-2,51)$, zakupów w supermarkecie w niedziele $(2,36-2,31)$. Ukazane wyniki badań pokazują, że w polskim społeczeństwie powoli zmienia się podejście do niedzielnego świętowania, co przejawia się w powolnej akceptacji zachowań, które kiedyś wzbudzały największą krytykę ${ }^{43}$. Ukazane tendencje powinny mobilizować do różnorodnych działań pastoralnych.

\section{Wnioski i postulaty}

Wyniki dotychczasowych badań skłaniają do podjęcia refleksji nad wytyczeniem różnych kierunków działań związanych z budowaniem kultury niedzieli.

\footnotetext{
${ }^{41}$ Badanym respondentom przedstawiono szereg zachowań będących wyrazem przeżywania czasu świątecznego i poproszono o ich ocenę w skali od 1 do 7 , na której 1 oznacza, że respondent nie ma nic przeciwko temu zachowaniu, natomiast 7 to ocena najbardziej rażącego go zachowania. Im wyższa średnia, tym większa krytyka społeczna danego zachowania. Zob. K. K o w a l c z u k: „Czas świateczny” czy ,czas tradycyjny” - o tradycjach wielkopostnych $i$ wielkanocnych oraz świętowaniu w niedzielę. Komunikat z badań. Warszawa 2010 s. 7.

42 Tamże.

${ }^{43}$ Tamże.
} 
Będąc służbą w obronie dnia Pańskiego, broni ona pierwiastka humanum w człowieku i społecznościach ${ }^{44}$.

Jan Paweł II w liście apostolskim Dies Domini podkreślił konieczność ponownego odkrycia głębokich uzasadnień doktrynalnych, ukazujących wartość niedzieli w życiu chrześcijanina (DD 6). Na kwestię tę trzeba spojrzeć w perspektywie budowania modelu świętowania dnia Pańskiego, u podstaw którego powinny leżeć działania związane z pogłębieniem rozumienia jego istoty i znaczenia. Wydaje się, że u źródeł niewłaściwego sposobu spędzania niedzieli przez część wiernych leży źle ukształtowana świadomość religijna, co przekłada się później na niepożądane zachowania. Badania pokazały, że w świadomości respondentów bardziej funkcjonował świecki wymiar niedzieli niż jej wymiar religijny. Wydaje się koniecznym nieustanne propagowanie treści zawartych w dokumentach Magisterium, dotyczących teologicznego znaczenia niedzieli, obejmujących zarówno jego wymiar horyzontalny, jak i wertykalny. Trzeba pokazywać, że dzień Pański jest darem Boga dla człowieka i społeczeństwa, umożliwiającym jego harmonijny rozwój. Brak odpowiedniej świadomości dotyczącej istoty niedzieli będzie zawsze skutkował podejmowaniem działań, których istota zaprzecza naturze jej świętowania. W tej perspektywie istnieje nagląca potrzeba pogłębiania teologii niedzieli. Postulowana formacja powinna odbywać się w ramach lekcji religii i katechez, szczególnie przy okazji przygotowania do przyjęcia Pierwszej Komunii św. i sakramentu bierzmowania. Działania formacyjne mają nie tylko obejmować dzieci i młodzież, ale również ich rodziców. Wspomnianą tematykę należy także poruszać w ramach homilii niedzielnych oraz misji i rekolekcji. Można też propagować ją w trakcie cotygodniowych kazań wygłaszanych z okazji różnego rodzaju nabożeństw. Tego rodzaju problematyka powinna stać się również przedmiotem spotkań formacyjnych w parafialnych grupach i wspólnotach religijnych.

Do propagowania treści ukazujących sposób świętowania niedzieli należy także wykorzystywać mass media, szczególnie prasę (w tym gazetki parafialne), oraz Internet (strony internetowe poszczególnych parafii i diecezji, katolickie portale internetowe itp). Powinny one wspierać wielorakie inicjatywy motywujące do właściwego przeżywania niedzieli, propagować sposoby godnego i wartościowego, służącego regeneracji całego człowieka, przeżywania czasu wolnego oraz ukazywać wielorakie korzyści płynące stąd dla rozwoju indywidualnego, rodzinnego i całego społeczeństwa. W tym kontekście rodzi się też postulat, aby parafie na szerszą skalę wydawały gazetki parafialne oraz prowadziły swoje strony internetowe, gdyż z badań prowadzonych przez ISKK SAC w 2011 r. wynika,

${ }^{44}$ B. N a d o $1 \mathrm{~s} \mathrm{k} \mathrm{i:} \mathrm{Antropologiczno-kulturowe} \mathrm{walory} \mathrm{niedzieli} w$ dzisiejszym społeczeństwie. W: E. Mateja, R. P i erskała (red.): Niedziela w społeczeństwie pluralistycznym. Opole 2001 s. 46-47. 
że na 11620 polskich parafii tylko jedna piąta (2 049) wydaje gazetki parafialne, a $40,0 \%$ z nich prowadzi strony internetowe ${ }^{45}$.

Mówiąc o działaniach z użyciem środków społecznego przekazu, należy zwrócić uwagę na wykorzystanie w duszpasterstwie reklamy religijnej, będącej częścią reklamy społecznej ${ }^{46}$. Można wykorzystywać właściwie przygotowane reklamy społecznej w celu motywowania członków społeczeństwa do dobrego przeżywania niedzieli. Przykładowo, może temu służyć przeprowadzenie kampanii społecznych z wykorzystaniem billboardów ulicznych oraz materiałów wywieszanych $\mathrm{w}$ gablotkach przykościelnych, ukazujących istotę niedzieli oraz założenie konta na największych portalach internetowych (facebook, twitter, nasza-klasa), przekazując informacje o sposobach oryginalnego i sprawdzonego spędzenia wolnego czasu z rodziną i pomysłach na umacnianie więzi rodzinnych. $\mathrm{Na}$ stronie internetowej powinny też być zamieszczane analizy najważniejszych metod manipulacji i perswazji stosowanych przez specjalistów od sprzedaży, pozwalające odbiorcom na bardziej świadome dokonywanie zakupów i ukazujące zagrożenia płynące $\mathrm{z}$ propagowanej kultury konsumpcjonizmu. Można też organizować, na wzór Orszaku Trzech Króli, marsze dla rodziny, kończące się piknikami i festynami, których celem będzie propagowanie idei powstrzymywania się od zakupów w niedzielę oraz wartości wspólnie przeżywanego czasu ${ }^{47}$.

\footnotetext{
${ }^{45}$ Zob. Instytut Statystyki Kościoła Katolickiego SAC i Główny Urząd Statystyczny: Kościót Katolicki w Polsce 1991-2012. Rocznik statystyczny. Warszawa 2014 s. 257.

${ }^{46}$ Reklama religijna to rodzaj reklamy społecznej, której celem jest wywołanie społecznie pożądanych postaw lub zachowań. Ma ona szczególne znaczenie w procesie nowej ewangelizacji - za jej pomocą można nie tylko oddziaływać na osoby zaangażowane religijne, ale również te będące na obrzeżach Kościoła lub dystansujące się od niego. Skuteczność reklamy religijnej (marketingu religijnego) wspierającej działania duszpasterskie zależy od zastosowanego w komunikacie języka, odwołania do specyficznych potrzeb i motywów zachowań różnych grup odbiorców, co w konsekwencji może prowadzić do zmian ich postaw i zachowań. Marketing religijny jest w Polsce dopiero w fazie początkowej, ponieważ wydaje się, że Kościół w naszym kraju posiada silną pozycję i nie czuje się zagrożony utratą znaczenia. Kryzys świętowania niedzieli, przejawiający się między w odwiedzaniu hipermarketów w niedziele, świadczy jednak o pewnej erozji tradycyjnych wartości i rywalizacji między światem religii a światem konsumpcji. Marketing religijny nie ma oczywiście zastępować podstawowego duszpasterstwa prowadzonego przez głoszone słowo Boże i sprawowanie sakramentów oraz życie wspólnotowe parafii, ale ma stanowić jego element pomocniczy. Zob. M. S u le j: Promowanie wiary i wartości chrześcijańskich poprzez reklamę. „Warszawskie Studia Pastoralne". R. 2009 nr 10 s. 100-109.

${ }^{47}$ Powyższe propozycje działań zostały przygotowane na drodze konsultacji z dr hab. Moniką Przybysz, adiunktem w Katedrze Public Relations i Komunikacji Marketingowej Instytutu Edukacji Medialnej i Dziennikarstwa Wydziału Teologicznego Uniwersytetu Kardynała Stefana Wyszyńskiego w Warszawie. Podkreśla ona, że w swoich działaniach pastoralnych Kościół powinien stosować zasady public relations, które są świadomym, planowym, i trwałym tworzeniem oraz utrzymywaniem pozytywnych relacji petnych wzajemnego zrozumienia i życzliwości między organizacja a społecznościq̨. Zwraca uwagę na to, że Kościół nie chce sprzedawać jakiegoś „towaru”, ale chce wykorzystać public relations jako nowoczesne narzędzie głoszenia słowa Bożego, wpisując je w nową koncepcję ewangelizacji. Szerszej na ten temat zob. M. Pr z y b y z: Public relations $w$
} 
W prowadzonych działaniach trzeba zarówno pokazywać wartość pracy, jak i odpoczynku, podkreślając konieczność zachowania harmonii miedzy tymi dwoma rodzajami aktywności ludzkiej. Człowiek nie może stać się niewolnikiem pracy, traktując ją w sposób bałwochwalczy. W kontekście wyników badań świadczących o tym, że część Polaków pracuje w niedzielę, warto ukazywać pozytywne skutki dobrze przeżytego czasu wolnego, który ma służyć rozwojowi osobowości oraz pogłębieniu więzi rodzinnych. W perspektywie tego, że wielu Polaków ceni sobie wartość życia rodzinnego ${ }^{48}$, należy zwracać uwagę na to, jak pozytywnie wpłynie na umacnianie więzi rodzinnych wspólnie przeżyty czas wolny. W tym kontekście należy również pokazywać wartość prawnego zakazu handlu w niedziele, który także umożliwi pracownikom sklepów spędzanie czasu $\mathrm{z}$ rodziną.

Aby umożliwić odpoczynek od pracy w niedziele, trzeba podejmować wysiłki prowadzące do tego, aby prawo państwowe gwarantowało prawo człowieka do odpoczynku oraz propagować inicjatywy zmierzające do ustawowego zakazu lub ograniczenia handlu w tym dniu ${ }^{49}$. Warto w tym kontekście ukazywać roz-

nowej ewangelizacji. W: W. P r z y g o d a, E. R o b e k (red.): Ewangelizacja odpowiedzia Kościoła w Polsce na wyzwania wspótczesności. Sandomierz 2011 s. 401-431; M. Prz y b y s z: Public Relations i reklama $w$ Kościele. W: M. P r z y b y s z, T. W i e 1 e b s k i (red.): Media $w$ duszpasterstwie. Warszawa 2014 s. 297-347.

${ }^{48} \mathrm{Z}$ badań prowadzonych przez ISKK SAC wynika, że w ciągu dwudziestu lat aż o 28,3 punkty procentowe wzrosło znaczenie przypisywane przez respondentów rodzinie, która stanowi dla nich wartość pierwszorzędną i bardzo dużą. Z kolei badania CBOS prowadzone w 2008 r. pokazują, że wśród najważniejszych wartości odgrywających znaczenie w życiu Polaków, ponad $78,0 \%$ ankietowanych wymienia rodzinę. Aż $66,0 \%$ deklaruje, że to właśnie wśród najbliższych najchętniej spełnia czas. Warto zwrócić uwagę na ten fakt przy motywowaniu wiernych do właściwego świętowania niedzieli, podkreślając, że dobre jego przeżycie wzmocni wspólnotę rodzinną. Zob. W. Ś w i ą t k i e w i c z: Między rodzina a życiem publicznym - ciaglość i zmiana orientacji na wartości w polskim spoteczeństwie. W: L. A d a m c z u k, E. F i r lit, W. Z d a n i e w i c z (red.): Postawy społeczno-religijne Polaków 1991-2012. Warszawa 2013 s. 192-194; R. B o g u s z e w s k i: Nie ma jak rodzina. Komunikat z badań. Warszawa 2008 s. 1-3.

${ }^{49}$ Zgodnie z artykułem $151^{9}$ § 1 obowiązującego w Polsce Kodeksu pracy, dniami wolnymi od pracy dla pracowników są niedziele i święta określone w przepisach o dniach wolnych od pracy. Ustawa z 18 stycznia 1951 roku o dniach wolnych od pracy wymienia: 1 stycznia (Nowy Rok); 6 stycznia (Święto Trzech Króli); Pierwszy i Drugi dzień Wielkiej Nocy; 1 maja (Święto Państwowe); 3 maja (Święto Narodowe 3 Maja); Pierwszy Dzień Zielonych Świątek; Boże Ciało; 15 sierpnia (Wniebowzięcie Najświętszej Maryi Panny); 1 listopada (Wszystkich Świętych); 11 listopada (Narodowe Święto Niepodległości); 25 i 26 grudnia (Pierwszy i Drugi dzień Bożego Narodzenia); wszystkie niedziele. Wspomniany przepis nie ustanawia bezpośredniego zakazu pracy w niedziele i święta, deklarując jedynie, że są to dni wolne od pracy. Począwszy od 1989 roku, różne środowiska pracownicze i społeczne w Polsce podejmowały liczne próby zmiany zapisów w Kodeksie pracy, mające na celu wprowadzenie całkowitego zakazu pracy placówek handlowych w niedziele. Przyjmowane się one jednak z wielkim oporem. Przykładowo, środowiska prawicowe próbowały w 2001 roku wprowadzić zmiany w Kodeksie pracy dotyczące zakazu handlu w niedziele w placówkach handlowych zatrudniających powyżej 5 osób. Projekt spotkał się z poparciem biskupów, którzy skierowali do ówczesnego prezydenta Aleksandra Kwaśniewskiego specjalny list. 
Podkreślali oni w nim między innymi, że odpoczynek niedzielny to nie tylko nakaz religijny, ale również podstawowe prawo człowieka. Zwrócili uwagę, że brak ustawowego zakazu handlu w niedziele, i wynikający stąd przymus pracy ze strony wielu pracodawców, prowadzi do poważnego konfliktu sumienia ludzi wierzących, którzy nie mają możliwości zgodnego z wiarą przeżywania niedzielnego, co jest łamaniem zasady wolności religijnej. Mimo poparcia biskupów, prezydent zawetował proponowane zmiany w Kodeksie pracy. Sprawa zakazu pracy w święta w placówkach handlowych stała się znowu aktualną w 2006 roku, gdy podjęta została inicjatywa ustawodawcza w kierunku zmiany przepisów Kodeksu pracy regulujących prace w niedziele i święta. Nowe przepisy w tym zakresie weszły w życie 26 października 2007 roku $^{49}$. W ramach nowelizacji został dodany do artykułu $151^{9 \mathrm{a}}$ przepis, w myśl którego jest niedozwolona praca w święta w placówkach handlowych $^{49}$. Dopuścił on jednak w nich prace w niedziele przy wykonywaniu prac koniecznych ze względu na ich użyteczność społeczna i codzienne potrzeby ludności (art. $151^{9 \mathrm{a}} \S 3$ ). Ustawodawca nie określił jednak kryteriów, jakie należy stosować przy ocenie poszczególnych prac, ani nie wprowadził generalnego zakazu prowadzenia działalności handlowej w dni świąteczne, lecz jedynie zakaz świadczenia pracy w tym dniu na podstawie umowy o pracę. Oznacza to, że właściciele obiektów handlowych nie łamią przepisów, pracując samodzielnie w tym dniu.

W 2013 r. znowu powróciła do publicznej dyskusji kwestia ustanowienia niedzieli jako dnia wolnego od pracy z jednoczesnym zakazem handlu w tym dniu. 24 maja 2013 r. w Sejmie została złożona poselska inicjatywa ustawodawcza, której pomysłodawcami byli posłowie z ruchów katolickich. Projekt podpisany przez 90. posłów, w zdecydowanej większości parlamentarzystów PiS, poparli też przedstawiciele PO, PSL oraz SP. Wywołał on ożywioną dyskusję dotyczącą ewentualnych strat $w$ gospodarce spowodowanych zakazem handlu w niedzielę, jednak wiele padających $w$ niej argumentów nie zostało popartych fachowymi analizami ekonomicznymi. Podobną inicjatywę legislacyjną dotyczącą zmiany Kodeksu pracy podjęli członkowie powstałego w kwietniu 2013 roku Obywatelskiego Komitetu Inicjatywy Ustawodawczej Ustawy „Wolna Niedziela”. Członkowie tego Komitetu, którego patronem jest Naczelna Rada Zrzeszeń Handlu i Usług, zbierają podpisy obywateli pod projektem ustawy wprowadzającym zakaz pracy w placówkach handlowych w każdą niedzielę. Twierdzą oni, że wprowadzenie w życie proponowanej zmiany Kodeksu pracy pociągnie za sobą bardzo korzystne skutki społeczne. Według nich zostanie stworzona nowa jakość życia rodzin, zwłaszcza tych, których członkowie są zatrudnieni w sektorze handlu, jak i rodzin nie związanych z działalnością handlową, a ogarniętych, pod wpływem reklamy, chęcią nieograniczonego robienia niekoniecznych zakupów. Komitet, odnosząc się do ewentualnych skutków gospodarczych i finansowych związanych z zakazem pracy w placówkach handlowych w niedziele, uważa, że nie powinno to skutkować większymi zmianami w szeroko rozumianej gospodarce kraju. Jego członkowie twierdzą, że z uwagi na to, że ilość środków dostępnych w budżetach domowych nie ulegnie zmianie, to zakupy zostaną rozłożone na sześć dni, a nie siedem. Według nich, ciężar zakupów niedzielnych przełożony zostanie na sobotę i poniedziałek. Będzie to oznaczać dla budżetu państwa to, iż wpływy z podatku VAT, CIT, PIT i akcyzy pozostaną na praktycznie niezmienionym poziomie. Uważają też, że zakaz pracy w placówkach handlowych w niedzielę nie spowoduje wzrostu bezrobocia, gdyż obowiązujący obecnie Kodeks pracy nakłada na pracodawcę obowiązek udzielenia pracownikowi dnia wolnego za przepracowaną niedzielę. Twierdzą, że uchwalony zakaz może przynieść dodatkowe miejsca pracy w jednostkach związanych z kulturą i wypoczynkiem. Obydwa projekty były rozpatrywane przez Sejm 21 III 2014 roku. Sejm odrzucił zarówno projekt poselski, jak i obywatelski, który został poparty przez 117 tysięcy obywateli.

${ }^{50}$ Niemiecka Agencja Katolicka KNA dokonała przeglądu regulacji prawnych dotyczących niedzieli i dni świątecznych w niektórych krajach europejskich. Przykładowo w Szwajcarii od końca 2007 r. władze kantonalne mogą zezwolić na handel w najwyżej cztery niedziele w roku. Handel w niedziele może się odbywać na większych dworcach, lotniskach i stacjach benzynowych. 
wolny od pracy, co ma miejsce w konstytucji niemieckiej. Do tego działań trzeba włączać nie tylko katolików, ale ludzi innych wyznań oraz niewierzących, wskazując, iż chodzi o niedzielę jako dobro publiczne i wartość kulturową. Jej znacznie kulturowe obejmuje zarówno wymiar osobisty (możliwość świętowania stwarza przestrzeń do zachowania nie zdeterminowanej pracą zawodową wolności osobowej), jak i wymiar społeczny (świętowanie pełni funkcję integracyjną). $\mathrm{W}$ prowadzonych debatach trzeba się również odwoływać do argumentów natury pozareligijnej.

Parafie powinny proponować różne formy spędzania wolnego czasu w niedzielę, odpowiadając na wielorakie oczekiwania respondentów. Z przeprowadzonych przez autora badań wynika, że respondenci negatywnie oceniają zaangażowanie swoich parafii na rzecz zagospodarowywaniu czasu wolnego: aż $65,5 \%$ osób badanych przez autora wspomina o braku możliwości spędzania $\mathrm{w}$ niedzielę czasu wolnego w parafialnym domu katolickim. Ważną rzeczą jest zwiększanie ich pozareligijnej oferty, która stworzy różne możliwości czynnego spędzania czasu wolnego. Jest to szczególnie ważne w sytuacji, gdy z powodu kryzysu wielu osób nie stać na kupno biletów do teatru czy do kina. Inną kwestią jest to, iż wiele osób nie potrafi dokonywać wartościowego wyboru spośród różnych propozycji kulturowych, karmiąc się jedynie wytworami kultury niższego $r z e ̨ d u$, będąc jej biernymi odbiorcami. Świadczą o tym badania pokazujące, że

We Włoszech czas pracy sklepów określają władze 20 regionów. W zasadzie w niedziele i święta wszystkie sklepy powinny być zamknięte, jedynie w grudniu właściciele mogą je, jeśli zechcą, otworzyć. Ponadto każda władza miejska może (w uzgodnieniu ze związkami zawodowymi), wydać specjalne zarządzenie w sprawie otwarcia sklepów w niedziele. Również każdy region może wyznaczyć miejsca w centrach turystycznych i w miejscowościach nadmorskich, gdzie sklepy mogą być otwarte w dowolnych porach. W Hiszpanii w niedzielne przedpołudnia klientów obsługują małe prywatne sklepiki lokalne. Ponadto w całym kraju sklepy mogą być otwarte w 12 niedziel w roku, między innymi w okresie przed Bożym Narodzeniem. Od 1994 r. w Anglii i Walii większe sklepy mogą być otwarte również w niedziele, ale tylko przez maksymalnie sześć godzin. W Niedzielę Wielkanocną i pierwszy dzień Bożego Narodzenia wszystkie sklepy są zamknięte. W Irlandii Północnej, pozostającej pod silnym wpływem Kościoła, przepisy są bardziej surowe. Od 1997 roku sklepy mogą być otwarte w niedzielne popołudnia, ale tylko maksymalnie przez pięć godzin. W Norwegii korzenie Ustawy o pokoju dni świątecznych sięgają 1735 r. - ostatnich zmian dokonano w 2003 roku. W dni powszednie czas pracy sklepów jest dowolny, natomiast w niedziele i święta mogą być otwarte tylko małe sklepy sprzedające przedmioty codziennego użytku. Wyjątek stanowią sklepy na stacjach benzynowych i w centrach turystycznych. W trzy ostatnie niedziele przez Bożym Narodzeniem wszystkie sklepy mogą pracować w godzinach popołudniowych. W Niemczech, od czasu reformy federalnej w 2006 r., kompetencje prawne dotyczące ustalania czasu otwarcia sklepów zostały przekazane poszczególnym krajom związkowym (landom). Handel w niedziele jest dozwolony w wyjątkowych przypadkach, najczęściej jednak tylko w cztery niedziele i dni świąteczne w roku (w Badenii-Wirtembergii tylko trzy, w Brandenburgii - sześć). Tylko w nielicznych landach w Adwencie sklepy mogą być otwarte tylko w jedną niedzielę. Wyjątek stanowią regiony turystyczne. TS: Niedzielne zakupy w Europie, http://ekai.pl/wydarzenia/temat_dnia /x43199/niedzielne-zakupy-w-europie/ (Odczyt: 10.08.2013). 
statystyczni Polacy najczęściej oglądają telewizję (prawie pięć godzin dziennie!), rzadko czytając książki. W tym kontekście należy podkreślić konieczność podejmowania wielorakich działań uczących wiernych właściwego gospodarowania czasem wolnym, będącym przecież darem Bożym. Mogą temu służyć działania podejmowane w ramach katechezy, głoszonych rekolekcji adwentowych i wielkopostnych i spotkań wielorakich grup ${ }^{51}$.

Biorąc pod uwagę różne oczekiwania mieszkańców parafii, należy zaproponować różne formy spędzania czasu wolnego. Badania autora pokazują, że w poglądach respondentów na temat danych form przeżywania czasu wolnego w parafiach, zauważa się pragnienie budowania relacji z innymi ludźmi oraz przeżyć służących rozwojowi ducha. Warto zestawić powyższe oczekiwania $\mathrm{z}$ wynikami badań pokazujących, jak duży procent Polaków robi zakupy w niedzielę. Wydaje się, że wśród osób odwiedzających wspótczesne świątynie konsuтрсјоnizmu część z nich nie ma zamiaru robienia zakupów, ale spędzenia czasu wolnego lub przezwyciężenia niedzielnej nudy. Trzeba właściwie odpowiedzieć na powyższe wezwania, szczególnie w kontekście narastającej anonimowości w parafiach miejskich i rosnącego poczucia osamotnienia, a także rosnącej pauperyzacji społeczeństwa, którego części nie stać na prowadzenie życia kulturalnego. Parafia ma stawać się oaza w pustynnym świecie, nie tylko zaspokajając potrzebę nawiązywania kontaktu z Bogiem, ale również z drugim człowiekiem. Budowaniu relacji międzyludzkich może przykładowo służyć działalność kawiarenki parafialnej, a jej prowadzenie można powierzać osobom świeckim, mającym do tego odpowiednie predyspozycje. Może ona rozprowadzać upieczone przez parafian ciasta, a dochód $\mathrm{z}$ ich sprzedaży może być przeznaczony na cele charytatywne. $\mathrm{Z}$ pewnością $\mathrm{w}$ większości miejskich parafii znajdą się artyści, pisarze czy poeci, którzy bezinteresownie będą chcieli się podzielić $\mathrm{z}$ innymi swoimi talentami i twórczością, a zebrane w czasie tych spotkań datki mogą być także przekazane na działalność charytatywną.

Mówiąc o inicjatywach, które mogą być realizowane w parafii, trzeba zauważyć pragnienie jednej piątej respondentów, aby stworzyć możliwość korzystania z wypożyczalni filmów i książek oraz czytania prasy. Biorąc pod uwagę katastrofalny stan czytelnictwa w Polsce (60,8\% Polaków nie przeczytało w 2012 roku żadnej książki), trzeba stwarzać możliwości kontaktu mieszkańców parafii ze słowem drukowanym. Prowadzenie takich wypożyczalni i czytelni prasy można też powierzać wolontariuszom, mającym do tego odpowiednie predyspozycje i czas. W parafiach mieszka przecież grupa emerytowanych nauczycieli czy osób z wyższym wykształceniem, którzy chętnie podejmą się tego typu działalności. Książki można pozyskiwać wieloma drogami, korzystając przykła-

${ }^{51}$ J. K o w a $1 \mathrm{~s}$ k i: Humanistyczny wymiar niedzieli. W: J. K r u c i n a (red.): Niedziela dzisiaj. Wrocław 1993 s. 144. 
dowo z rabatów udzielanych przez wydawnictwa stałym nabywcom albo prosząc parafian o przekazywanie własnych książek. Można też stworzyć w parafii wypożyczalnię wartościowych filmów, niosących ze sobą przesłanie religijne i humanistyczne, , jak też organizować na miejscu ich pokazy, wiążąc to z dyskusją po ich projekcji. Wydaje się, że takie Parafialne Kluby Filmowe mogą skupiać osoby, pragnące w sposób twórczy przeżywać wspólnie niedzielny czas. Warto też pomyśleć o stworzeniu w parafii kawiarenki internetowej, z której mogłaby korzystać szczególnie młodzież i dzieci, zwłaszcza z rodzin ubogich.

Ważne jest budzenie wśród wiernych świadomości, że niedziela ma być dniem, w którym będą się oni poświęcać dziełom miłosierdzia i działalności charytatywnej. Wysoki wskaźnik procentowy osób, które nie podejmują tego typu inicjatyw $(71,3 \%)$ powinien pobudzać do odpowiednich działań. Jednym z kierunków działań jest zmiana świadomości, dotycząca konieczności zaangażowania charytatywnego wszystkich wiernych tworzących wspólnotę Kościoła. Nie wszyscy katolicy właściwe rozumieją rolę i istotę zaangażowania charytatywnego, co przekłada się na motywację i decyzję osobistego działania. Wykorzystując dostępne formy działalności formacyjnej, trzeba nieustannie podkreślać, że realizacja funkcji charytatywnej Kościoła jest istotowo związana z jego tożsamością. Współczesny świat potrzebuje Kościoła stużacego ubogim, wśród których jest wiele osób chorych, niepełnosprawnych i samotnych. Należy zachęcać wiernych do odwiedzania ich w domach oraz w szpitalach, hospicjach, dzieci w domach dziecka, więźniów. Parafianie mają też zadbać o to, aby osoby niepełnosprawne, które pragną wziąć udział we mszy św. w niedzielnej, a mają trudności w samodzielnym poruszaniu, mogły dotrzeć do świątyni. Potrzeba też tworzenia w parafiach klubów seniora, gdzie osoby starsze i samotne będą mogły twórczo przeżywać czas.

Wielorakie działania dotyczące kształtowania kultury niedzieli powinny być również realizowane na poziomie ponadparafialnym. Warto w tym kontekście odwołać się do działalności Społecznego Ruchu Świętowania Niedzieli, który powstał i działa na terenie diecezji legnickiej. Skupia on różne środowiska diecezji legnickiej (solidarnościowe zrzeszenia pracownicze, diecezjalne stowarzyszenia katolickie, instytucje społeczno-medialne, i inne), pragnące wprowadzać w życie przesłanie Jana Pawła II zawarte w liście apostolskim Dies Domini. Każdy z członków ruchu podpisał deklarację ideową. Znajduje się w niej przyrzeczenie troski o świąteczny charakter niedzieli, szerzenia w przestrzeni społecznej wartości tego dnia, podejmowania działań prowadzących do zmiany prawa i stylu życia oraz powstrzymywanie się od robienia zbędnych zakupów w niedzielę. Uczestnicy ruchu deklarują też, że nie podejmą pracy w niedzielę, kierując się chciwością lub pragnieniem zaspokojenia potrzeb konsumpcyjnych, a będąc pracodawcą - nie zmuszać innych do pracy kosztem ich więzi z Bogiem, 
rodzina i wspólnota, $w$ której żyją ${ }^{52}$. Podejmują oni różne inicjatyw służące zmianie świadomości dotyczącej wartości niedzieli i jej obrony. Na szeroką skalę prowadzą działania propagujące deklarację ideową tego ruchu a także książkę zawierającą niedzielny dekalog katolika ${ }^{53}$. Organizują konferencje prasowe podejmujące kwestie świętowania niedzieli, prowadzą stronę internetową, na której umieszczają informacje poświęcone wspomnianej problematyce, biorą udział w licznych konferencjach formacyjnych na szczeblu diecezjalnym i ogólnopolskim. W 2011 r. członkowie Ruchu wraz z księżmi proboszczami przygotowali i rozwiesili 700 plakatów z napisem Niedziela jest święta, a 6 stycznia 2012 roku zorganizowali, przebiegający pod hasłem Pamiętaj, abyś dzień święty świecil, Pierwszy Legnicki Marsz Trzech Króli ${ }^{54}$. Z ich inicjatywy w styczniu 2011 roku w Sejmie odbyła się konferencja poświęcona świątecznemu charakterowi niedzieli. Wydaje się, że warto skorzystać z przykładu wielorakich działań Ruchu, podejmując je w skali ogólnopolskiej.

Mówiąc o wielorakich inicjatywach służących kształtowaniu kultury niedzieli, należy zwrócić uwagę na wykorzystanie w działalności duszpasterskiej dnia 3 marca $^{55}$. W tym dniu w wielu krajach obchodzi się Europejski Dzień Wolnej Niedzieli, którego inicjatywa jest również popierana przez Komisję Episkopatów Wspólnoty Europejskiej (COMECE). Rozpropagowanie w Polsce tego dnia na różnych poziomach życia Kościoła, we współpracy ze wszystkimi środowiskami społecznymi walczącymi o prawo pracowników do odpoczynku oraz obchodzenie go przykładowo w najbliższą niedzielę po tej dacie, dawałoby dobrą okazję do zwrócenia uwagi na problematykę przeżywania dnia Pańskiego w wielu jego aspektach. Międzynarodowy Dzień Wolnej Niedzieli może służyć podejmowaniu różnorodnych akcji kształtujących świadomość znaczenia tego dnia i podkreślających właściwe postawy ${ }^{56}$.

${ }^{52}$ B. W o lań ski: Niedziela dniem Pańskim i świętem rodziny. „Teologia Praktyczna”. T. 12: 2011 s. 86.

${ }^{53}$ 1. Pomyśleć o Bogu i wieczności; 2. Uczestniczyć we mszy św. i zadbać o wspólna modlitwę; 3. Przeżyć czas w gronie rodziny i przyjaciół; 4. Przeznaczyć czas na odpoczynek na łonie natury; 5. Pamiętać o lekturze Pisma Świętego i literatury religijnej; 6. Znaleźć czas na rozmowy rodzinne; 7. Pamiętać o chorych i samotnych; 8. Odwiedzić groby zmarłych; 9. Zadbać o świąteczny posiłek przy rodzinnym stole; 10 . Podkreślić dzień świąteczny odświętnym strojem - Zob. B. W o 1 a ń s k i: Niedzielny dekalog katolika. W: B. D ro ż ḋ̇, B. W o 1 a ń s k i (red.): Niedziela jest święta, dz. cyt., s. 22.

${ }^{54}$ B. W o 1 a ń s k i: Społeczny Ruch Świętowania niedzieli. W: Komisja Duszpasterstwa Konferencji Episkopatu Polski: Być sola ziemi. Kościót domem i szkoła komunii. Program duszpasterski Kościoła w Polsce na lata 2010-2013,. Red. Sz. S t u ł k o w s k i . Poznań 2010 s. 408-411.

553 marca 321 r. cesarz Konstantyn wydał dekret ustanawiający niedzielę, zwaną czcigodnym Dniem Słońca, państwowym dniem wolnym od pracy.

564 marca 2013 r. związkowcy ze związku zawodowego „Solidarność” rozdali 20 tysięcy ulotek promujących idee ustanowienia niedzieli dniem wolnym od pracy w handlu. Akcja została przeprowadzona przed centrami handlowymi w Warszawie, Katowicach, Krakowie, Białymstoku, 
Mamy świadomość, że w tego typu publikacji nie sposób wyczerpująco przedstawić wszystkie aspekty poruszanego zagadnienia ${ }^{57}$. Warto jednak na koniec zwrócić uwagę, że zawarte w niej sugestie widzieć trzeba w kontekście nowej ewangelizacji, nawrócenia pastoralnego i duszpasterstwa misyjnego, do którego wzywa papież Franciszek w adhortacji Evangelii gaudium (EG 1-15; 25). Kościół ma podążać droga duszpasterskiego i misyjnego nawrócenia, które nie może pozostawić rzeczy $w$ takim stanie, w jakim sa (EG 25). Duszpasterstwo $\mathrm{w}$ kluczu misyjnym wymaga rezygnacji z wygodnego kryterium duszpasterskiego, że »zawsze się tak robiło«, co wiąże się odwagą, kreatywnością i przemyśleniem na nowo celów, stylu i metod ewangelizacyjnych (EG 33).

Ponieważ głównym źródłem zapału misyjnego uczniów Chrystusa jest ich aktywny udział w Eucharystii, szczególnie niedzielnej i świątecznej, trzeba więc, na co zwraca dokument podsumowujący V Ogólną Konferencję Episkopatów Ameryki Łacińskiej zwany dokumentem z Aperecidy ${ }^{58}$, promować program duszpasterski niedzieli i w programach duszpasterskich (...) przyjąc go za priorytet jako nowy impuls w ewangelizacji Ludu Bożego na Kontynencie latynoamerykańskim (AP 251-252).

Ten postulat nie odnosi się tylko do osób zamieszkujących inne kontynenty, ale również Polskę. W dużej mierze nawrócenie pastoralne i duszpasterstwo w kluczu misyjnym wiąże się z podjęciem refleksji nad tym, jakie działania powi-

Bydgoszczy, Łodzi, Rzeszowie, Lubinie, Głogowie i Gdańsku, spotykając się z bardzo pozytywną reakcją przechodniów. Była ona częścią ogólnoeuropejskiej kampanii Europejskiego Przymierza na Rzecz Wolnej Niedzieli, stowarzyszenia zrzeszającego związki zawodowe oraz organizacje pozarządowe z całego kontynentu, którego „Solidarność” jest członkiem-współzałożycielem. Zob. Europejski Dzień Wolnej Niedzieli, http://www.wolnaniedziela.pl/index.php?pokaz=nowy_marzec (Odczyt: 30.08.2013).

Warto w tym kontekście odwołać się do kampanii prowadzonej w diecezji w Padwie we Włoszech przeciwko handlowi w niedzielę. Inicjatorzy akcji, nawołując do bojkotu niedzielnego handlu, zapewniają, że zależy im przede wszystkim na zmianie stylu życia wiernych. Ks. Adriano Sella, koordynator kampanii, podkreślił, że to nie jest krucjata przeciwko supermarketom. Chodzi raczej o ponowne odkrycie wartości czasu odpoczynku, rodziny, relacji międzyludzkich. Pomysł kampanii i sposób jej prowadzenia uzyskał błogosławieństwo ordynariusza diecezji abpa Antonia Mattiazzo. Akcja objęła wszystkie tamtejsze parafie i stowarzyszenia katolickie. Po zakończeniu niedzielnych mszy św. osoby wychodzące z kościoła otrzymywały do podpisania deklarację, w której zobowiązywały się do nie robienia zakupów w niedziele. Sporządzono także tzw. białą listę sklepów zamkniętych $\mathrm{w}$ dni świąteczne, które to listy zostały wywieszona w parafiach. W witrynach tych sklepów umieszczono także hasła zachęcające wiernych do tego, aby tylko tam robili w tygodniu zakupy. Zob. Niedziela? Nie kupuję. Stop niedzielnym zakupom w Padwi. „Internetowy Dziennik K@tolicki”. Data wydania 12 XI 2012, http://nowy.ekai.pl/szuflada/ protected/183424/axrdgbpe9zieod0p/ (Odczyt: 30.08.2013).

${ }^{57}$ Więcej zob. T. W i e le b s k i: Dzień Pański w życiu katolików w Polsce. Studium pastoralnoteologiczne. Warszawa 2013.

${ }^{58}$ Zob. APARECIDA. V Ogólna Konferencja Episkopatów Ameryki Łacińskiej i Karaibów. Dokument końcowy Jesteśmy uczniami i misjonarzami Jezusa Chrystusa, aby nasze narody miaty w nim życie. Tłum. K. Z a b a w a, K. Ł u k a s z c z y k. Gubin 2014 (dalej: AP). 
nien podjąć Kościół w Polsce, aby nauczenia Magisterium dotyczące przeżywania niedzieli, zarówno w aspekcie wertykalnym, jak i horyzontalnym było właściwie realizowane, wpisując się w nurt nowej ewangelizacji. 